\title{
Dolomite-rich coralline algae in reefs resist dissolution in acidified conditions
}

\author{
M. C. Nash ${ }^{1 \star}$, B. N. Opdyke ${ }^{2}$, U. Troitzsch ${ }^{2}$, B. D. Russell ${ }^{3}$, W. H. Adey ${ }^{4}$, A. Kato ${ }^{5}$, G. Diaz-Pulido ${ }^{6}$, \\ C. Brent ${ }^{2}$, M. Gardner ${ }^{2}$, J. Prichard ${ }^{2}$ and D. I. Kline $\mathrm{P}^{7,8}$
}

Coral reef ecosystems develop best in high-flow environments but their fragile frameworks are also vulnerable to high wave energy. Wave-resistant algal rims, predominantly made up of the crustose coralline algae (CCA) Porolithon onkodes and $\boldsymbol{P}$. pachydermum $^{1,2}$, are therefore critical structural elements for the survival of many shallow coral reefs. Concerns are growing about the susceptibility of CCA to ocean acidification because CCA Mg-calcite skeletons are more susceptible to dissolution under low pH conditions than coral aragonite skeletons ${ }^{3}$. However, the recent discovery ${ }^{4}$ of dolomite $\left(\mathrm{Mg}_{0.5} \mathrm{Ca}_{0.5}\left(\mathrm{CO}_{3}\right)\right)$, a stable carbonate ${ }^{5}$, in $\boldsymbol{P}$. onkodes cells necessitates a reappraisal of the impacts of ocean acidification on these CCA. Here we show, using a dissolution experiment, that dried dolomite-rich CCA have 6-10 times lower rates of dissolution than predominantly $\mathrm{Mg}$-calcite CCA in both high$\mathrm{CO}_{2}(\sim 700 \mathrm{ppm})$ and control ( $\left.\sim 380 \mathrm{ppm}\right)$ environments, respectively. We reveal this stabilizing mechanism to be a combination of reduced porosity due to dolomite infilling and selective dissolution of other carbonate minerals. Physical break-up proceeds by dissolution of $\mathrm{Mg}$-calcite walls until the dolomitized cell eventually drops out intact. Dolomite-rich CCA frameworks are common in shallow coral reefs globally and our results suggest that it is likely that they will continue to provide protection and stability for coral reef frameworks as $\mathrm{CO}_{2}$ rises.

Coralline algae form extensive carbonate structures on the highenergy windward side of many tropical coral reefs. For example, the algal rim on the fringing reef of Rodrigues Island (Indian Ocean) is $\sim 11 \mathrm{~km}$ long, $4 \mathrm{~m}$ thick and in parts protrudes $\sim 1 \mathrm{~m}$ above the reef flat $^{6}$, providing substantial protection for island communities from high-energy waves. Only the surface veneer (the top few millimetres) of CCA is living ${ }^{7}$ and the dense carbonate underneath the algal rim is predominantly in situ CCA skeleton and overlapping layers of coral branches cemented together by CCA crusts ${ }^{6}$. Development of these reef structures is dependent on preservation of the dead CCA skeleton post-mortem. Thus, understanding how declining seawater $\mathrm{pH}$ will affect this skeletal preservation is of paramount importance if we are to understand the changes to coral reef structural stability in a high- $\mathrm{CO}_{2}$ world.

In the 1950s-1970s the mineral composition of coralline algae skeletons was determined to be $\sim 12-18 \mathrm{~mol} \% \mathrm{Mg}$-calcite ${ }^{8-10}$. However, many bulk chemical analyses of tropical coralline algae showed a surplus of magnesium compared with those determined by X-ray diffraction (XRD) using Mg-calcite peak position ${ }^{8,9}$. Recently, we discovered this discrepancy was due to the presence of previously undetected dolomite and magnesite $\left(\mathrm{MgCO}_{3}\right)$ forming within the cell spaces ${ }^{4}$. Past determinations of thermodynamic solubility for coralline algae were based on the assumption that they were composed of $\mathrm{Mg}$-calcite $\mathrm{in}^{10-12}$. As dolomite was not believed to form in the modern marine environment, determining dolomite solubility under these conditions was considered of limited importance ${ }^{12}$. Dolomite stability has been inferred from the geologic record with a noted correlation between dolomite abundance and periods of higher $\mathrm{CO}_{2}$ (lower $\mathrm{CO}_{3}$ saturation state) in the Phanerozoic eon ${ }^{5}$ indicating dolomite stability under lower $\mathrm{pH}$ conditions.

We carried out dissolution experiments on fragments $\left(\sim 1 \mathrm{~cm}^{3}\right)$ of CCA ( $P$. onkodes) collected fresh, then dried, from the Heron Island reef front (Great Barrier Reef, Australia) and exposed to ambient sea water as a control and an enriched $\mathrm{CO}_{2}$ treatment (Methods). $\mathrm{pH}$ (National Bureau of Standards scale) ranged from 7.85 to 8.55 (control) and 7.69-8.44 (treatment) tracking natural diurnal changes measured in the lagoon water ${ }^{13}$ (Supplementary Tables S1-S3 and Figs S1 and S2). Weight changes from experiments using living CCA are a combination of growth processes and skeletal dissolution ${ }^{14}$. Previous dissolution experiments have used dried, powdered CCA (refs 10,11), in beakers, with $\mathrm{pH}$ conditions not representative of the coral reef environment. The aim of this experiment was to determine the relationship between the mol\% $\mathrm{MgCO}_{3}$ of the CCA skeleton and dissolution without the influence of living processes. Although it was necessary to dry the CCA until dead, the crusts were kept intact so as to obtain results most closely replicating dissolution of exposed skeleton in the natural environment. Understanding this non-biotic dissolution process is important because when the CCA skeleton is exposed in the reef, for example by bio-erosion or breakages, then, without the protection of organic membranes, dissolution will be constrained by the skeletal composition (mineral and structural) $)^{12}$.

Considering the prevailing theories that $\mathrm{Mg}$-calcites with higher $\mathrm{Mg}$ content will undergo greatest dissolution, we were surprised to find a trend in the opposite direction (Fig. 1a). After ten days in the control and $\mathrm{CO}_{2}$ treatments, coralline algae from the higher mol\% group (17.27- $18 \mathrm{~mol} \% \mathrm{MgCO}_{3}$; by XRD, Methods) had significantly less $(p<0.001)$ weight loss than the lower mol\% group $\left(16.3-17.45 \mathrm{~mol} \% \mathrm{MgCO}_{3}\right)$. The higher $\mathrm{mol} \%$ group had

\footnotetext{
${ }^{1}$ Research School of Physics, The Australian National University, Acton, Australian Capital Territory 0200, Australia, ${ }^{2}$ Research School of Earth Sciences, The Australian National University, Acton, Australian Capital Territory 0200, Australia, ${ }^{3}$ Southern Seas Ecology Laboratories, School of Earth and Environmental Sciences, University of Adelaide, Adelaide, South Australia 5005, Australia, ${ }^{4}$ National Museum of Natural History, Smithsonian Institution, Washington DC 20013, USA, ${ }^{5}$ Takehara Fisheries Research Station, Center for Education and Research of Field Science, Hiroshima University, Minato-machi, Takehara, Hiroshima 725-0024, Japan, ${ }^{6}$ Griffith School of Environment and Australian Rivers Institute-Coast and Estuaries, Griffith University, Brisbane, Nathan, Queensland 4111, Australia, ${ }^{7}$ Scripps Institution of Oceanography, University of California, San Diego, La Jolla, California 92093, USA, ${ }^{8}$ Coral Reef Ecosystems Laboratory, School of Biological Sciences, University of Queensland, Brisbane, Queensland 4072, Australia. *e-mail: merinda.nash@anu.edu.au.
} 


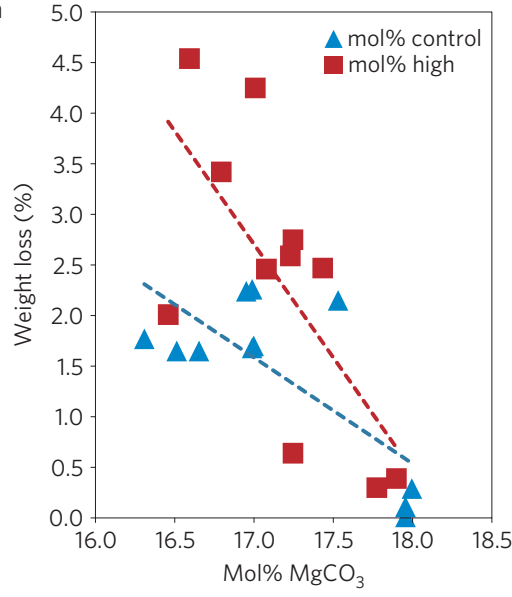

b

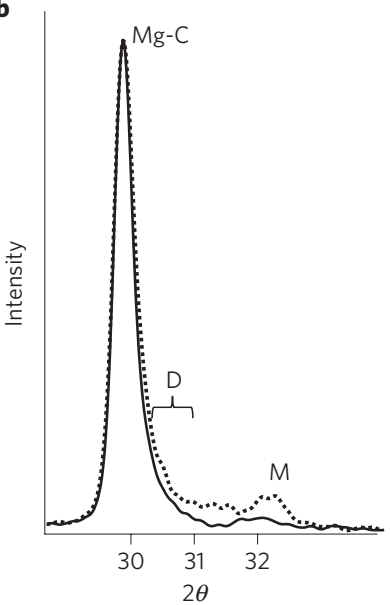

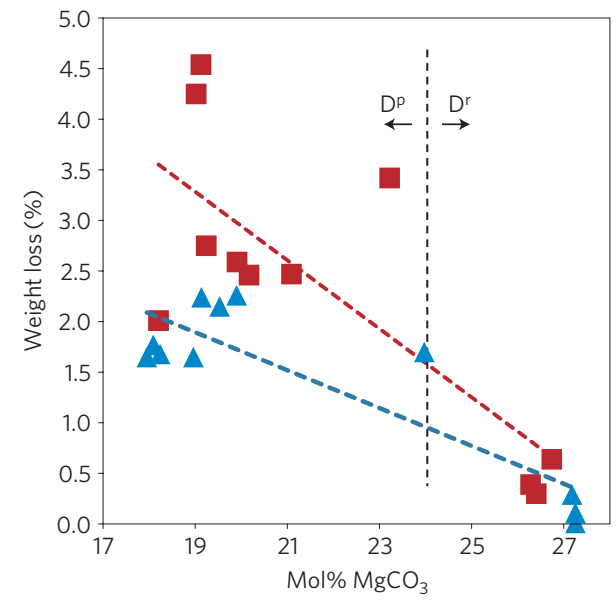

Figure 1 | Dependence of weight loss of coralline algae on composition ( $\left.\mathrm{mol} \% \mathrm{MgCO}_{3}\right)$. a, Weight loss versus $\mathrm{Mg}$-calcite composition, showing a trend for higher weight loss with lower $\mathrm{Mg}$ content in both control $(R=-0.74)$ and high $(R=-0.69) \mathrm{CO}_{2}$ treatment samples. The slopes are significantly different (Supplementary Table S3b). The more Mg-rich CCA have the most asymmetrical Mg-calcite XRD peaks. Mg contents determined using the Mg-calcite peak position. b, Typical XRD scans for $D^{r}$ (dotted line) and $D^{P}$ CCA (solid line). Mg-C, Mg-calcite; D, dolomite range (M.C.N. et al., manuscript in preparation); $M$, magnesite. $\mathbf{c}$, Weight loss versus $\mathrm{Mg}$-calcite composition as determined using the asymmetrical peak position (M.C.N. et al., manuscript in preparation; asymm mol\%; Supplementary Fig. S3). Compared with a, which shows the same samples, the regression has improved, with control $(R=-0.87)$ and high $\mathrm{CO}_{2}(R=-0.77)$. The slopes are significantly different (Supplementary Table S3b).

an average weight loss of $0.17 \%$ (s.d. 0.13 ) and $0.51 \%$ (s.d. 0.19 ), respectively, which was $\sim 91 \%$ and $83 \%$ less than the lower mol\% group (Supplementary Table S3a). This trend was also observed in a five-day in situ ocean acidification experiment ${ }^{15}$. The $\mathrm{Mg}$-calcite XRD peaks for the more Mg-rich CCA demonstrated extreme asymmetry (Fig. 1b), which we discovered indicated the presence of dolomite and magnesite ${ }^{4}$. The less Mg-rich CCA showed only slight asymmetry and this was confirmed to represent a lesser amount of dolomite. We developed a simple technique to numerically describe this asymmetry (M.C.N. et al., manuscript in preparation; Supplementary Fig. S3) and found a negative correlation between this dolomite and magnesite asymmetry and weight loss (Fig. 1c); control: $R=-0.87(p=0.01)$, and high $\mathrm{CO}_{2}: R=-0.77(p=0.01$; statistics summary Supplementary Table S3b). We classify the CCA with asymmetry $>24 \mathrm{~mol} \% \mathrm{MgCO}_{3}$ as dolomite rich $\left(\mathrm{D}^{\mathrm{r}}\right)$ and those $<24 \mathrm{~mol} \% \mathrm{MgCO}_{3}$ as dolomite poor ( $\mathrm{D}^{\mathrm{p}}$ ) (Methods).

Next, to understand the differences between the $\mathrm{D}^{\mathrm{r}}$ and $\mathrm{D}^{\mathrm{p}}$ CCA that could be constraining the dissolution, we compared the physical distribution of dolomite within the $\mathrm{D}^{\mathrm{r}}$ and $\mathrm{D}^{\mathrm{p}}$ CCA (scanning electron microscopy (SEM), Methods). The key difference was that only the $\mathrm{D}^{\mathrm{r}}$ CCA had dolomite lining the regular cell spaces (Fig. 2a), whereas $\mathrm{D}^{\mathrm{p}}$ had $\mathrm{Mg}$-calcite (Fig. 2b). Both $\mathrm{D}^{\mathrm{r}}$ and $\mathrm{D}^{\mathrm{p}}$ CCA had cell infill commencing $\sim 50-100 \mu \mathrm{m}$ below the surface. In $\mathrm{D}^{\mathrm{r}} \mathrm{CCA}$ this cell infill could be magnesite (Fig. 2c) or dolomite, whereas in $\mathrm{D}^{\mathrm{p}} \mathrm{CCA}$, cells were either left void or infilled with $\mathrm{Mg}$-calcite (Fig. 2d) and infrequently, magnesite (Supplementary Fig. S4). Dolomite lining in the $\mathrm{D}^{\mathrm{r}}$ CCA formed as rhombs and submicrometre-sized mounds (Fig. 2e-g). In both the $\mathrm{D}^{\mathrm{p}}$ and $\mathrm{D}^{\mathrm{r}}$ CCA the reproductive conceptacles contained dolomite (Fig. 3a,b, enlargements Supplementary Figs S5 and S6). A particularly intriguing difference in their natural dissolution process is revealed in the bottom $100 \mu \mathrm{m}$; the $\mathrm{D}^{\mathrm{r}} \mathrm{CCA}$ was visibly dense whereas that of the $\mathrm{D}^{\mathrm{p}}$ CCA was mostly porous owing to limited cell infill (Fig. 3c,d). We used a gridded point count (Supplementary Information) to estimate the porosity for $\mathrm{D}^{\mathrm{r}}$ CCA at $6 \%$ and $\mathrm{D}^{\mathrm{p}} \mathrm{CCA}$ at $65 \%$, a figure that closely matched the tenfold difference in dissolution between the $\mathrm{D}^{\mathrm{r}}$ and $\mathrm{D}^{\mathrm{p}}$ CCA. We estimate that the stable dolomite reduces the reactive surface area in $\mathrm{D}^{\mathrm{r}}$ CCA by $\sim 45 \%$ (estimated from the point count). The net dissolution process seems to be one of selective mineral dissolution and precipitation. In the base of the $\mathrm{D}^{\mathrm{r}} \mathrm{CCA}, \mathrm{Mg}$-calcite fills cells, magnesite was absent and the dolomite rims remained intact, thus retaining density. In contrast, in the $\mathrm{D}^{\mathrm{p}}$ CCA the cell infill and interfilament $\mathrm{Mg}$-calcite had dissolved, and only the cell-lining Mg-calcite remained. It seems that the process of physical break-up in the $\mathrm{D}^{\mathrm{r}}$ CCA occurs through the dissolution of the interfilament and cell-wall Mg-calcite until sufficient wall material has been removed for the dissolution-resistant dolomite cell cast to drop out intact (Fig. 4a,b). These dolomite cell casts are not only thermodynamically stable but also physically harder than the surrounding Mg-calcite (Fig. 4c). In the $\mathrm{D}^{\mathrm{r}} \mathrm{CCA}$, alteration to mineralogy seems to commence about $500-600 \mu \mathrm{m}$ up from the base (Supplementary Fig. S7) and similarly in the $D^{\mathrm{p}}$ CCA. Aragonite also infilled discrete cells (Supplementary Fig. S8) and replaced parts of the CCA skeleton. The common Mg-calcite cell infill in the $\mathrm{D}^{\mathrm{p}}$ and absence from the $\mathrm{D}^{\mathrm{r}}$ (excluding the exposed base) implies that it is unlikely that the $D^{p}$ is a mid-stage in the formation of $\mathrm{D}^{\mathrm{r}} \mathrm{CCA}$. Some CCA had XRD asymmetry that was between $\mathrm{D}^{\mathrm{r}}$ and $\mathrm{D}^{\mathrm{p}}$; SEM revealed banding of layers with and without dolomite rims and little cell infill (Supplementary Fig. S9).

To confirm the sequence of mineral dissolution and removal we performed an etching experiment on the $\mathrm{D}^{\mathrm{r}}$ and $\mathrm{D}^{\mathrm{p}}$ CCA (Methods). We found no evidence of cell rim dolomite dissolution; however, dolomite seems to be removed from conceptacles (Supplementary Fig. S10). In both samples the interfilament Mgcalcite is preferentially removed followed by the cell wall $\mathrm{Mg}$ calcite (Supplementary Fig. S11a-f). Freshwater experiments on dolomite limestone have demonstrated that dissolution rates of dolomite are independent of $\mathrm{pH}$ between 6 and 8 (ref. 16) and that water flow velocity is the strongest control on dissolution rates of calcite ${ }^{17}$. Indeed, pore space and permeability are the key parameters influencing skeletal breakdown in temperate coralline algae in undersaturated conditions ${ }^{18}$. We propose that stability of the $\mathrm{D}^{\mathrm{r}} \mathrm{CCA}$ is conferred by their low porosity reducing water flow velocity throughout the lower crust, thereby reducing all dissolution reaction rates ${ }^{17,19}$ and allowing re-precipitation of $\mathrm{Mg}$-calcite within cell spaces. These processes combined result in a net physical break-up to an order of magnitude less than that for $\mathrm{D}^{\mathrm{p}} \mathrm{CCA}$ without dolomite cell lining. The degree of this stability will be influenced by the quantity of dolomite and cell infill. 

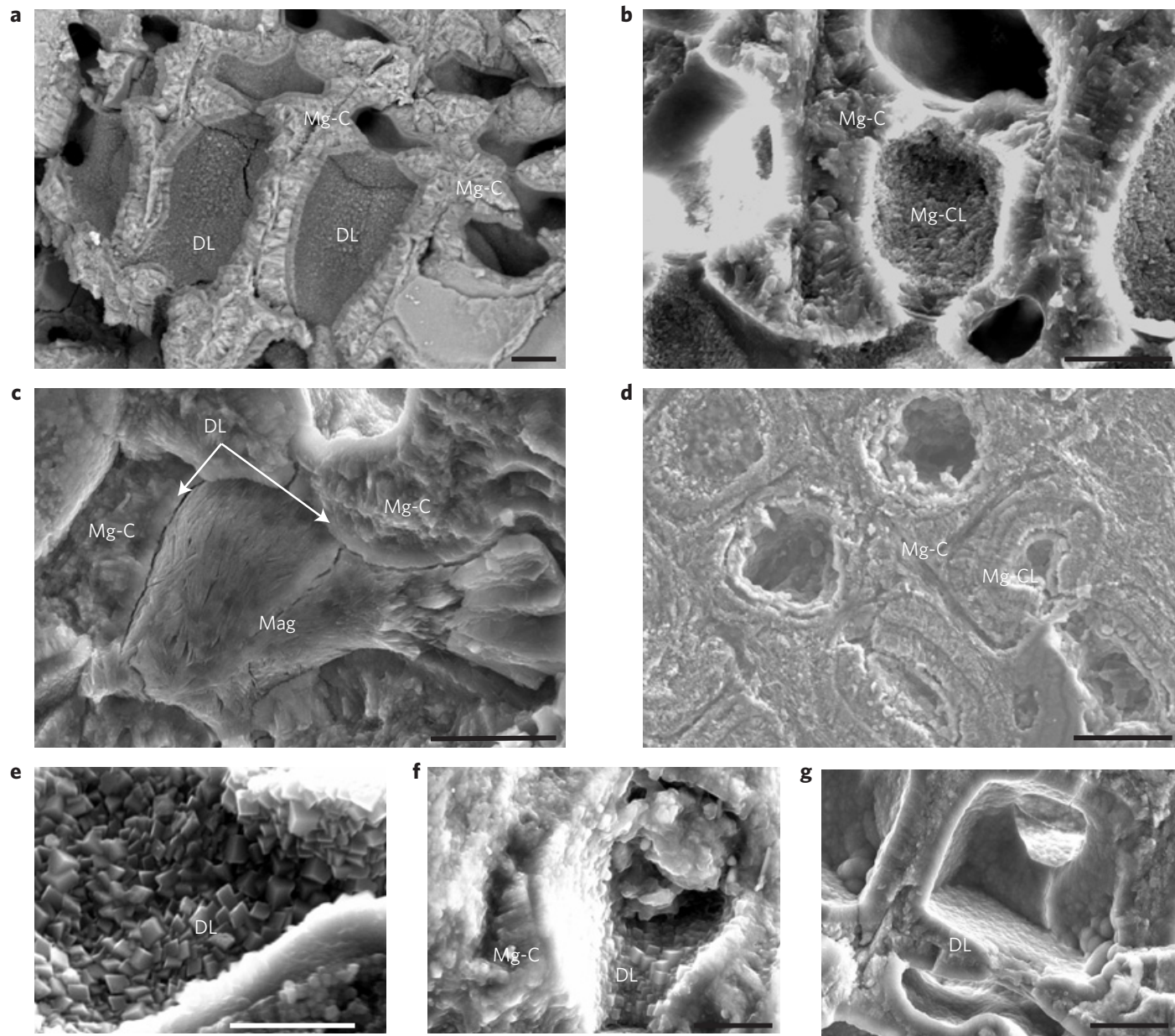

Figure 2 | Comparison of intracellular mineralization in the $D^{r}$ and $D^{p}$ coralline algae. $\mathbf{a}, D^{r} C C A(H 305)$ has cells lined with dolomite (DL), whereas cell walls and interfilament calcified areas are composed of $\mathrm{Mg}$-calcite $(\mathrm{Mg}-\mathrm{C})$. b, $\mathrm{D}^{\mathrm{p}} \mathrm{CCA}$ (H311) shows cells with an $\mathrm{Mg}$-calcite lining (Mg-CL). c, $\mathrm{D}^{r} \mathrm{CCA}$ (H305) has magnesite (Mag) cell infill. Dolomite lining (white arrows) forms a narrow rim between the Mg-calcite cell wall and the cell infill. $\mathbf{d}$, $\mathrm{D}^{p}$ CCA (H56) has cell infill by concentric rings of Mg-calcite. e, $D^{r}$ CCA (H305); close up of dolomite rhombs forming cell lining. $\mathbf{f}_{\text {, }}(\mathrm{H} 305)$ dolomite cell infill with organic coating. $\mathbf{g}$, CCA (H320) shows dolomite rims with dolomite submicrometre-sized mounds on the surface. Scale bars, $5 \mu \mathrm{m}(\mathbf{a}-\mathbf{d})$ and $2 \mu \mathrm{m}(\mathbf{e}-\mathbf{g})$.

The next question is how prevalent is this dolomite phenomenon? To answer this we determined the mineralogy of samples collected from multiple coral reefs from the Pacific and Caribbean. We found $\mathrm{D}^{\mathrm{r}}$ CCA in our samples from shallow reef locations at Heron Island (southern Great Barrier Reef), Lizard Island (northern Great Barrier Reef), Okinawa (northern Pacific) and the Caribbean (Supplementary Table S5 and Figs S12 and S13). Dolomite was most commonly found in dense crusts $(>3 \mathrm{~mm})$ from high-energy, light environments and was absent from thin crusts growing in shaded locations. CCA skeleton in a reef front algal rim core $^{6}$ from Rodrigues (Indian Ocean) demonstrated asymmetry comparable to $\mathrm{D}^{\mathrm{r}}$ of fresh CCA (Supplementary Table S5 and Figs S14-S16). These samples were from 35 to $80 \mathrm{~cm}$ and $3.2 \mathrm{~m}$ down core, an estimated age of $290-670 \mathrm{yr}$ and $2,670 \mathrm{yr}$, respectively, indicating that this biomineralized dolomite is stable long after the organism has died. We reviewed previous studies that recorded bulk magnesium measurements higher than $\sim 18 \mathrm{~mol} \% \mathrm{MgCO}_{3}$ or XRD asymmetry (for example, refs $8,9,20$ ) to determine whether these CCA may have had the type of dolomite mineralization we have detailed here. Every one of the six coral reefs in those studies had algal-ridge-building CCA with bulk magnesium amounts or XRD profiles that matched our assessment for $\mathrm{D}^{\mathrm{r}}$, five of these with magnesite, (Supplementary Tables S6a-d and Fig. S17) and included multiple species. By combining these published reports with our results we demonstrate that $\mathrm{D}^{\mathrm{r}} \mathrm{CCA}$ are present in the tropical Indian, Atlantic, North and South Pacific oceans (Supplementary Map S1). Dolomite was not detected in temperate samples in our study (three locations) or in the reviewed studies, suggesting that its formation may be primarily constrained by temperature. These results are in accord with evidence from the geological record for a correlation with higher temperatures and dolomite formation ${ }^{5}$.

The final question of importance is whether these $\mathrm{D}^{\mathrm{r}} \mathrm{CCA}$ will continue to survive and produce dolomite under predicted future $\mathrm{CO}_{2}$ levels. Previous studies have suggested that CCA may be susceptible to ocean acidification ${ }^{14,21,22}$; however, not all have found negative outcomes ${ }^{23}$. Crucially, none of these studies replicated the high-energy environments in which the $\mathrm{D}^{\mathrm{r}}$ crusts form. The low dissolution rates for the $\mathrm{D}^{\mathrm{r}} \mathrm{CCA}$ in our experimental high- $\mathrm{CO}_{2}$ treatment demonstrate that these CCA skeletons are unlikely to suffer annual net dissolution in this scenario. The reef front does not experience the extreme diel $\mathrm{pH}$ fluctuations as used in our experiment; this will probably further reduce dissolution rates and the net impact will be also be governed by biological tissue coverings, reef attachment, growth and bio-erosion ${ }^{14}$. The high dissolution rate for the $\mathrm{D}^{\mathrm{p}} \mathrm{CCA}$ is concerning as this indicates that there may be no contribution to the reef lagoon sediment from their skeletons as $p_{\mathrm{CO}}$ approaches the experimental levels of $\sim 500-700 \mathrm{ppm}$.

Although the exact process driving dolomite formation in the CCA has yet to be determined, considering the abundance of 

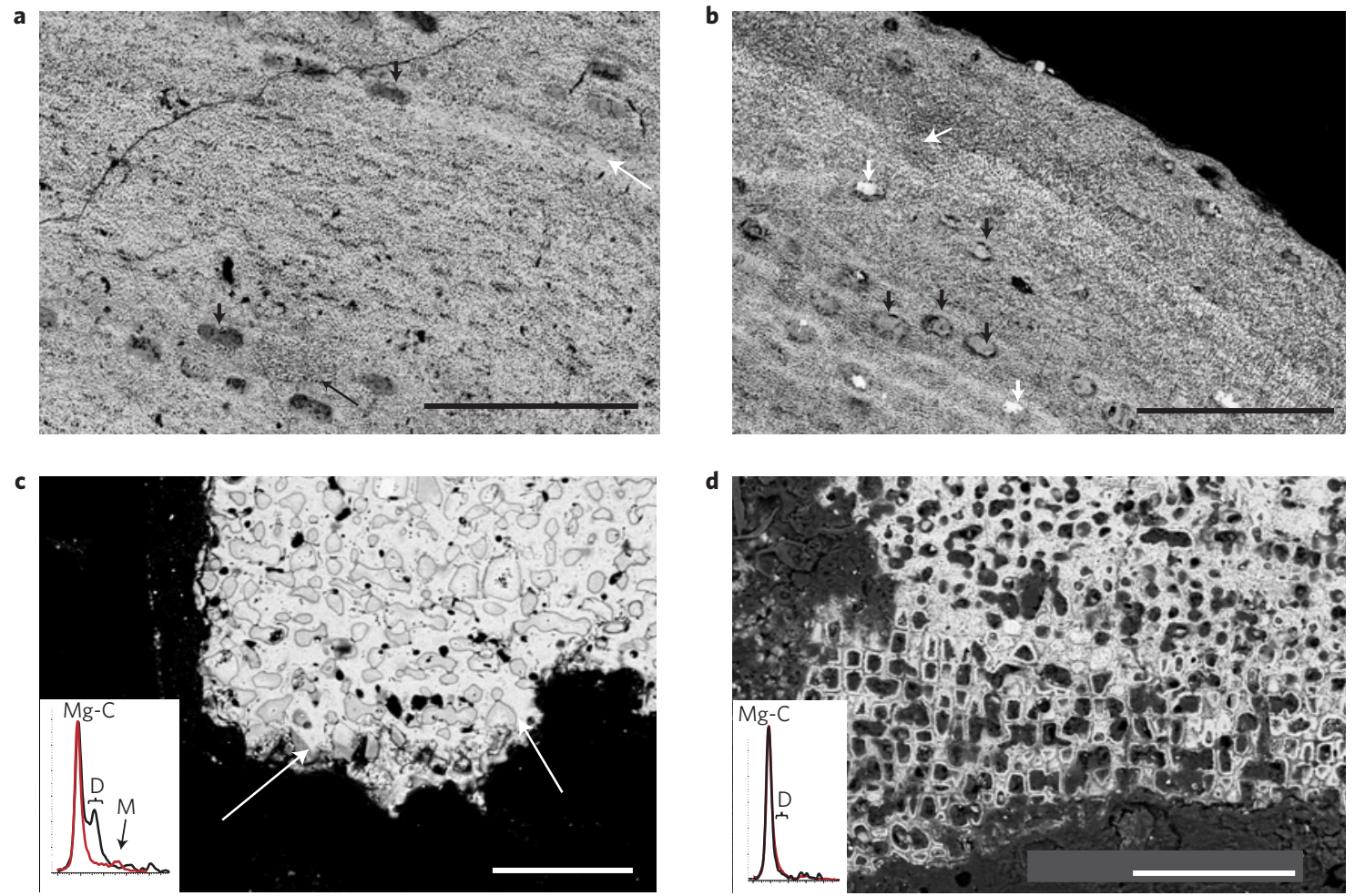

Figure 3 | Overview of $D^{r}$ and $D^{p}$ coralline algae with evidence of natural dissolution processes at the base exposed to sea water and corresponding XRD patterns. Both samples were living at the time of collection and were kept out of the experimental tanks as dry controls. $\mathbf{a}, D^{r}$ CCA-dolomite and magnesite fill the conceptacles (thick black arrows). Banding of dolomite cell infill (white arrow) and magnesite infill (thin black arrow) suggests a seasonal influence on mineralization; scale bar, $1 \mathrm{~mm}$ (enlargements Supplementary Figs S6 and S7). b, D ${ }^{p}$ CCA-dolomite (dark grey) is detected only in reproductive conceptacle spaces (black arrows), whereby some conceptacles have normal cell regrowth (narrow white arrow). Small patches of aragonite (white) infill (thick white arrows) are common; scale bar, $1 \mathrm{~mm}$. c, $D^{r}$ CCA-rims remain dolomite (white arrows) as in layers above; cell infill is now only $\mathrm{Mg}$-calcite with no magnesite remaining; scale bar, $50 \mu \mathrm{m}$. XRD (inset) of this bottom layer (black) shows the Mg-calcite (Mg-C) peak and the separate peak for dolomite $(D)$, and the magnesite peak $(M)$ is absent compared to the total sample (red). d, $D^{p}$ CCA-cell rims are Mg-calcite (light grey). Cells are empty (black) or infilled with Mg-calcite. Fluffy black material over cells is resin; scale bar, $100 \mu \mathrm{m}$. Mg-calcite XRD (inset) peak shows minimal dolomite asymmetry in the base layer (black), which is marginally less than for the total sample (red).

sedimentary dolomite in greenhouse epochs $s^{5}$ and the evidence for an organic driver ${ }^{4,24,25}$, it is reasonable to suggest that dolomite biomineralization is not inhibited by low saturation state. Support for this notion comes from a recent study demonstrating that dolomite can form abiotically in red algae polysaccharide solutions at starting pH of 7.7-7.9 (ref. 24). Interestingly, magnesium uptake was positively correlated with polysaccharide concentration. CCA are rich in polysaccharides $^{26}$ and light can concentrate polysaccharides at the cell perimeter of red algae $e^{27}$. In addition, dolomite formation seems to occur as a process of cell infilling in cells not in direct contact with external water conditions. Considering these studies together with our observations, it seems probable that dolomite mineralization in the CCA is not driven primarily by seawater saturation state. Rather, mineralization is probably reliant on, first, the provision of sufficiently concentrated nucleating sites (organic templates with the CCA), perhaps driven by light and temperature; the subsequent dolomite mineralization may then depend on a further set of suitable environmental conditions, possibly the key being temperature.

Although our data show $\mathrm{D}^{\mathrm{r}}$ CCA with cell infill are not impervious to increasing dissolution under both present and higher $\mathrm{CO}_{2}$, this distinctive dolomite intracellular calcification clearly provides substantial resistance to dissolution in comparison with predominantly Mg-calcite CCA. Laboratory experiments used to determine $\mathrm{Mg}$-calcite dissolution rate data resulted in diagenetic outcomes, that is, the formation of substantial amounts of calcite (for example, ref. 10), that were not observed in our samples (Supplementary Fig. S17). This suggests that the dissolution data derived from these experiments and subsequent comparisons to aragonite may not be applicable to CCA in their natural environment. We do not ignore that reef stability may be reduced under projected future conditions; however, the stability of dolomite-enriched algal ridge coralline algae offers a positive light in a potentially gloomy future for coral reefs. Until the process and drivers of dolomite formation are understood, the biological response of CCA to higher $\mathrm{CO}_{2}$ (and probably temperature), and therefore its ultimate contribution to reef stability, will remain uncertain.

\section{Methods}

CCA P. onkodes were collected for the dissolution experiment from the reef front of Heron Island in 2009 (details in ref. 4). Crusts collected had pink living surfaces and exposed bases and were broken off the reef, not dug out. Four crusts of fresh CCA were cleaned by hand of any epiphytes and loose material using a small wooden pick and brush; no chemical cleaning was applied. These crusts were broken into 25 pieces of approximately $1 \mathrm{~cm}^{3}$. They were sun dried for two days including cleaning time, in the oven at $40^{\circ} \mathrm{C}$ for $9 \mathrm{~h}$ and confirmed as no longer photosynthetically active, using a pulse-amplitude-modulated fluorometer. All samples were subject to an equal amount of drying time before the experiment. CCA were dry weighed to the nearest milligram, sensitivity $\pm 0.001 \mathrm{~g}$. The CCA pieces were randomly distributed between the control $(n=3)$ and treatment $(n=3)$ flow-through tanks (tank set-up, flow-through system and $\mathrm{CO}_{2}$ control are as described in refs 15,28). Dry controls were kept and not used in the experiment to identify any changes in mineralogy due to treatment effect; the XRD results were comparable to samples from both control and treatment tanks (Supplementary Table S3a). After ten days in treatment tanks, samples were sun dried for seven days and re-weighed. All samples were subject to an equal amount of drying time after the experiment. There was no correlation between starting weight and weight lost. Dissolved inorganic carbon and alkalinity in tanks were determined as in ref. 15. A Mettler Toledo 


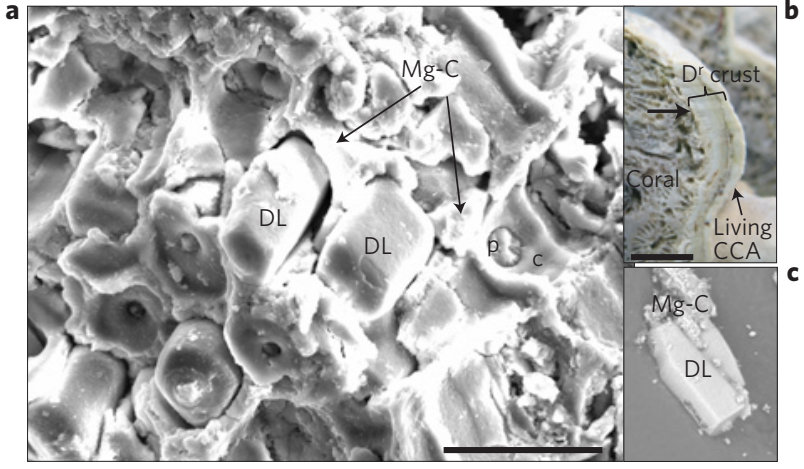

Figure $4 \mid D^{r}$ CCA crust on coral branch. Example of the natural break-up of the CCA crust (the surface of this 1-cm-thick crust was living at the time of collection, collected from Heron reef front 0-2 m depth). a, SEM of dolomite cells at the base of a $D^{r}$ CCA (H601). The Mg-calcite cell wall is disintegrating, leaving the dolomite casts of the cells ( $D L$ ) protruding until sufficient framework has been removed so that the cell casts drop out. p, Mg-calcite pit connector; c, cell wall interior; scale bar, $20 \mu \mathrm{m}$. b, Living coralline (H601) overgrowing coral. There is a visible gap between the CCA and the coral where the base of the CCA was exposed to sea water; wide arrow-location of SEM image in a; pink surface is the living coralline layer and dolomite infill starts 100-200 $\mu \mathrm{m}$ down into the crust. It is not known whether the dolomite fills in living or dead cells; scale bar, $1 \mathrm{~cm}$. c, Lowest layer subsample (H305) after grinding in a mortar and pestle for XRD, demonstrating that dolomite casts are resistant to grinding whereas the surrounding $\mathrm{Mg}$-calcite has been reduced to a submicron size.

$\mathrm{pH}$ meter was used for discrete $\mathrm{pH}$ measurements. XRD was undertaken after the completion of the experiment. XRD and SEM with energy-dispersive spectroscopy followed ${ }^{4}$ and the dolomite range was determined as in M.C.N. et al. (manuscript in preparation). For classification of $\mathrm{D}^{\mathrm{r}}$ versus $\mathrm{D}^{\mathrm{p}} \mathrm{CCA}$ we classify those above 24 asymm. mol\% as $\mathrm{D}^{\mathrm{r}}$; however, we also compare XRD peak asymmetry shape to check that the dolomite asymmetry matches samples with $\mathrm{D}^{\mathrm{r}}$ mineralogy as confirmed by SEM (as detailed in Fig. 2). Visual inspection of the XRD for the two samples just less than $24 \mathrm{~mol} \%$ showed that the curve in the dolomite slope was less than that for samples with $\mathrm{D}^{\mathrm{r}}$ mineralogy (see legend to Supplementary Table S5 for further discussion).

For etching, polished samples in resin were placed in a $200 \mathrm{ml}$ beaker of deionized water with the $\mathrm{pH}$ adjusted by the addition of $\mathrm{HNO}_{3}$ or $\mathrm{HCl}$. In the first etching for $1 \mathrm{~h}$, the $\mathrm{pH}$ ranged from 7.98-8.01; in the second etching for $6 \mathrm{~h}$, the $\mathrm{pH}$ ranged from 7.7-7.82. The water was stirred continuously and the temperature ranged from 25 to $28^{\circ} \mathrm{C}$. To assess the mineralogy of previous studies, information on XRD and bulk magnesium was compared with that from our studies where mineralogy had also been confirmed by SEM with energy-dispersive spectroscopy.

Received 4 July 2012; accepted 31 October 2012; published online 9 December 2012

\section{References}

1. Littler, M. M. \& Doty, M. S. Ecological components structuring seaward edges of Tropical Pacific reefs: Distribution, communities and productivity of Porolithon. J. Ecol. 63, 117-129 (1975).

2. Adey, W. H. \& Macintyre, I. G. Crustose coralline algae: A re-evaluation in the geological sciences. Geol. Soc. Am. Bull. 84, 883-904 (1973).

3. Bischoff, W. D., Bishop, F. C. \& Mackenzie, F. T. Biogenically produced magnesian calcite: In homogeneities in chemical and physical properties; comparison with synthetic phases. Am. Mineral. 68, 1183 (1983).

4. Nash, M. C. et al. First discovery of dolomite and magnesite in living coralline algae and its geobiological implications. Biogeosciences 8, 3331-3340 (2011).

5. Wilkinson, B. W. \& Given, R. K. Secular variation in abiotic marine carbonates: Constraints on phanerozoic atmospheric carbon dioxide contents and oceanic $\mathrm{Mg} /$ Ca ratios. J. Geol. 94, 321-333 (1986).

6. Rees, S. A., Opdyke, B. N., Wilson, P. A. \& Fifield, L. K. Coral reef sedimentation on Rodrigues and the Western Indian Ocean and its impact on the carbon cycle. Phil. Tran. R. Soc. A 363, 101-120 (2005).

7. Adey, W. H. Review: Coral reefs: Algal structured and mediated ecosystems in shallow, turbulent, alkaline waters. J. Phycol. 34, 393-406 (1998).
8. Chave, K. E. Aspects of the biogeochemistry of magnesium 1. Calcareous marine organisms. J. Geol. 62, 266-283 (1954).

9. Milliman, J. D., Gastner, M. \& Muller, J. Utilization of magnesium in coralline algae. Geol. Soc. Am. Bull. 82, 573-580 (1971).

10. Plummer, L. N. \& Mackenzie, F. T. Predicting mineral solubility from rate data: Application to the dissolution of magnesian calcites. Am. J. Sci. 274, 61-83 (1974).

11. Bischoff, W. D., Mackenzie, F. T. \& Bishop, F. C. Stabilities of synthetic magnesian calcites in aqueous solution: Comparison with biogenic materials. Geochim. Cosmochim. Acta 51, 1413-1423 (1987).

12. Morse, J. W., Arvidson, R. S. \& Luttge, A. Calcium Carbonate formation and dissolution. Chem. Rev. 107, 342-381 (2007).

13. Santos, I. R., Glud, R. N., Maher, D. \& Eyre, B. D. Diel coral reef acidification driven by pore water advection in permeable carbonate sands, Heron Island, Great Barrier Reef. Geophys. Res. Lett. 38, L03604 (2011).

14. Diaz-Pulido, G., Anthony, K. R. N., Kline, D. I., Dove, S. \& Hoegh-Guldberg, $\mathrm{O}$. Interactions between ocean acidification and warming on the mortality and dissolution of coralline algae. J. Phycol. 48, 32-39 (2012).

15. Kline, D. I., Teneva, L., Schneider, K., Miard, T. \& Chai, A. et al. A short-term in situ $\mathrm{CO}_{2}$ enrichment experiment on Heron Island (GBR). Sci. Rep. 2, 413 (2012).

16. Pokrovsky, O. S. \& Schott, J. Kinetics and mechanism of dolomite dissolution in neutral to alkaline solutions revisited. Am. J. Sci. 301, 597-626 (2001).

17. Al-Kawaz, H. A. Dissolution Rate Constant of Carbonates under Natural Environments. Tikrit J. Pure Sci. 15 (3), 84-90 (2010).

18. Henrich, R. \& Wefer, G. Dissolution of biogenic carbonates: Effects of skeletal structure. Mar. Geol. 71, 341-362 (1986).

19. Opdyke, B. N., Gust, G. \& Ledwell, J. R. Mass transfer from smooth alabaster surfaces in turbulent flows. Geophys. Res. Lett. 14, 1131-1134 (1987).

20. Clarke, F. W. \& Wheeler, W. C. The Inorganic Constituents of Marine Invertebrates (USGS, 1922).

21. Kuffner, I. B., Andersson, A. J., Jokiel, P. L., Rodgers, K. S. \& Mackenzie, F. T. Decreased abundance of crustose coralline algae due to ocean acidification. Nature Geosci. 1, 114-117 (2008).

22. Anthony, K. R. N., Kline, D. I., Diaz-Pulido, G., Dove, S. \& Hoegh-Guldberg, O. Ocean acidification causes bleaching and productivity loss in coral reef builders. Proc. Natl Acad. Sci. USA 105, 17442-17446 (2008).

23. Ries, J. B., Cohen, A. L. \& McCorkle, D. C. Marine calcifiers exhibit mixed responses to $\mathrm{CO}_{2}$-induced ocean acidification. Geology 37, 1131-1134 (2009).

24. Zhang, F., Xu, H., Konishi, H., Shelobolina, E. S. \& Roden, E. E. Polysaccharide-catalyzed nucleation and growth of disordered dolomite: A potential precursor of sedimentary dolomite. Am. Mineral. 97, 556-567 (2012).

25. Krause, S. et al. Microbial nucleation of Mg-rich dolomite in exopolymeric substances under anoxic modern seawater salinity: New insight into an old enigma. Geology 40, 587-590 (2012).

26. Bilan, M. I. \& Usov, A. I. Polysaccharides of calcareous algae and their effect on the calcification process. Russ. J. Bioorg. Chem. 27, 2-16 (2001).

27. Ramus, J. The production of extracellular polysaccharide by the unicellular red algae Porphyridium aerugineum. J. Phycol. 8, 97-111 (1972).

28. Doropoulos, C., Ward, S., Diaz-Pulido, G., Hoegh-Guldberg, O. \& Mumby, P. J. Ocean acidification reduces coral recruitment by disrupting intimate larval-algal settlement interactions. Ecol. Lett. 15, 338-346 (2012).

\section{Acknowledgements}

Thanks to F. Brink and the team at the ANU Centre for Advanced Microscopy for assistance with SEM work, A. Harvey for CCA samples from Victoria, L. Teneva for differential interference contrast analyses, J. Caves for field work assistance, the FOCE team and staff at Heron Island Research Centre, J. W. Lai and D. Nash for sample preparation. S. Connell for assistance with Heron experiments and J. Roberts for assistance with SEM.

\section{Author contributions}

M.C.N. and B.N.O. designed initial project; M.C.N., B.D.R. and D.I.K. carried out Heron Island experimental work and water chemistry measurements; U.T. assisted with subsequent analyses and project design. G.D-P., sample identification and design of experimental tank facilities; A.K. and W.H.A., sample collection and identification. M.C.N., U.T. and W.H.A., SEM. M.C.N. and U.T., XRD analysis. C.B., M.G. and J.P., sample collection, survey, XRD and data analyses. M.C.N. and U.T. wrote and edited the manuscript and all authors contributed.

\section{Additional information}

Supplementary information is available in the online version of the paper. Reprints and permissions information is available online at www.nature.com/reprints. Correspondence and requests for materials should be addressed to M.C.N.

\section{Competing financial interests}

The authors declare no competing financial interests. 


\section{Dolomite-rich coralline algae in reefs resist dissolution in acidified}

\section{conditions}

\section{Carbonate chemistry data for dissolution experiments}

\begin{tabular}{|c|c|c|c|c|c|c|c|}
\hline & \multicolumn{3}{|c|}{ Control pH } & \multicolumn{3}{|c|}{ High $\mathrm{CO}_{2} \mathrm{pH}$} & \multirow[t]{2}{*}{$\begin{array}{l}\text { av. } \\
\text { Temp. } \\
{ }^{\circ} \mathrm{C} \\
\end{array}$} \\
\hline & Tank 1 & Tank 2 & Tank 3 & Tank 4 & Tank 5 & Tank 6 & \\
\hline avg & 8.17 & 8.15 & 8.15 & 7.88 & 7.90 & 7.84 & 26.90 \\
\hline st. dev & 0.17 & 0.18 & 0.15 & 0.17 & 0.17 & 0.16 & 1.77 \\
\hline lowest & 7.87 & 7.85 & 7.87 & 7.68 & 7.69 & 7.64 & 25 \\
\hline highest & 8.55 & 8.52 & 8.43 & 8.16 & 8.3 & 8.14 & 30.5 \\
\hline range & 0.68 & 0.67 & 0.56 & 0.48 & 0.61 & 0.5 & 5.5 \\
\hline
\end{tabular}

Table 1: Summary of measured $\mathrm{pH}$ and temperature in tanks.

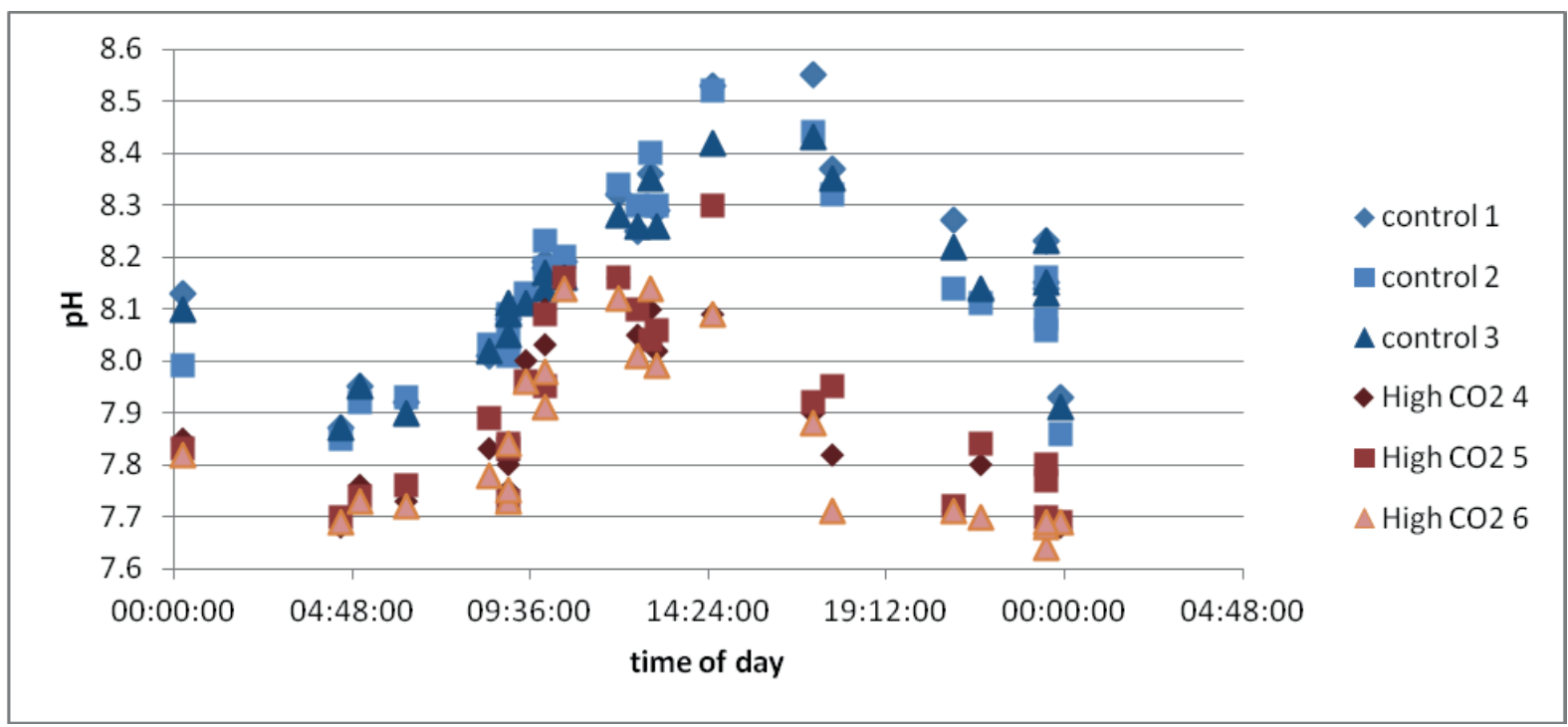

Figure 1: Comparison of control and treatment measured $\mathrm{pH}$. Treatment $\mathrm{pH}$ tracks control by $\sim-0.2$ $\mathrm{pH}$ from midnight to noon, larger offset of -0.3-0.4 during later afternoon / early evening. 


\begin{tabular}{|c|c|c|c|c|c|c|c|c|c|c|}
\hline & averages $\mathrm{c}$ & ntrol & & & & averages $h$ & $\mathrm{gh} \mathrm{CO}_{2}$ & & & \\
\hline $\begin{array}{l}\mathrm{CO}_{2} \text {-sys } \\
\text { constants }\end{array}$ & $\begin{array}{l}11 / 12 \\
5.30 \mathrm{am}\end{array}$ & $\begin{array}{l}12 / 12 \\
12.00\end{array}$ & $\begin{array}{l}13 / 12 \\
6 \mathrm{pm}\end{array}$ & \begin{tabular}{|l|}
$14 / 12$ \\
$4.30 \mathrm{am}$ \\
\end{tabular} & $\begin{array}{l}15 / 12 \\
11 \mathrm{pm}\end{array}$ & $\begin{array}{l}11 / 12 \\
5.30 \mathrm{am}\end{array}$ & $\begin{array}{l}12 / 12 \\
12.00\end{array}$ & $\begin{array}{l}13 / 12 \\
6 \mathrm{pm} \\
\end{array}$ & $\begin{array}{l}14 / 12 \\
4.30 \mathrm{am}\end{array}$ & $\begin{array}{l}15 / 12 \\
11 \mathrm{pm}\end{array}$ \\
\hline Salinity & 34.70 & 34.70 & 34.77 & 34.80 & 34.83 & 34.70 & 34.70 & 34.77 & 34.80 & 34.70 \\
\hline Temp & 25.70 & 29.97 & 28.13 & 25.37 & 25.97 & 25.70 & 29.57 & 27.57 & 25.50 & 26.33 \\
\hline $\begin{array}{l}\text { Total } \\
\text { carbon }\end{array}$ & 1972.37 & 1779.24 & 1742.32 & 2132.37 & 1874.75 & 2034.24 & 1938.95 & 2086.47 & 2170.58 & 2055.03 \\
\hline $\begin{array}{l}\text { Total } \\
\text { Alkalinity }\end{array}$ & 2284.07 & 2258.77 & 2237.80 & 2287.83 & 2221.33 & 2302.30 & 2271.97 & 2222.93 & 2295.50 & 2208.83 \\
\hline $\mathrm{pH}$ total & 8.06 & 8.25 & 8.30 & 7.76 & 8.12 & 7.98 & 8.04 & 7.69 & 7.68 & 7.75 \\
\hline $\mathrm{HCO}_{3}$ & 1740.65 & 1444.81 & 1399.64 & 1984.20 & 1625.32 & 1827.21 & 1693.68 & 1947.54 & 2034.08 & 1910.59 \\
\hline $\mathrm{CO}_{3}$ & 221.06 & 329.15 & 337.95 & 123.83 & 240.81 & 193.74 & 235.24 & 111.93 & 106.74 & 120.95 \\
\hline $\mathrm{pCO}_{2}$ & 382.64 & 209.83 & 180.18 & 866.90 & 311.98 & 477.35 & 395.03 & 1015.22 & 1063.63 & 856.70 \\
\hline Omega-C & 5.34 & 8.02 & 8.20 & 2.99 & 5.81 & 4.68 & 5.73 & 2.71 & 2.58 & 2.93 \\
\hline $\begin{array}{l}\text { Omega- } \\
\text { A }\end{array}$ & 3.53 & 5.37 & 5.46 & 1.97 & 3.84 & 3.09 & 3.83 & 1.80 & 1.70 & 1.94 \\
\hline
\end{tabular}

Table 2: Calculated carbonate parameters using $\mathrm{CO}_{2}$-sys (following ref. 30), High $\mathrm{CO}_{2}$ tracks control by $\sim+200 \mathrm{ppm}$ in the morning and $+500-800 \mathrm{ppm}$ in the evening. 


\section{Comparison of pH data to lagoon measurements}

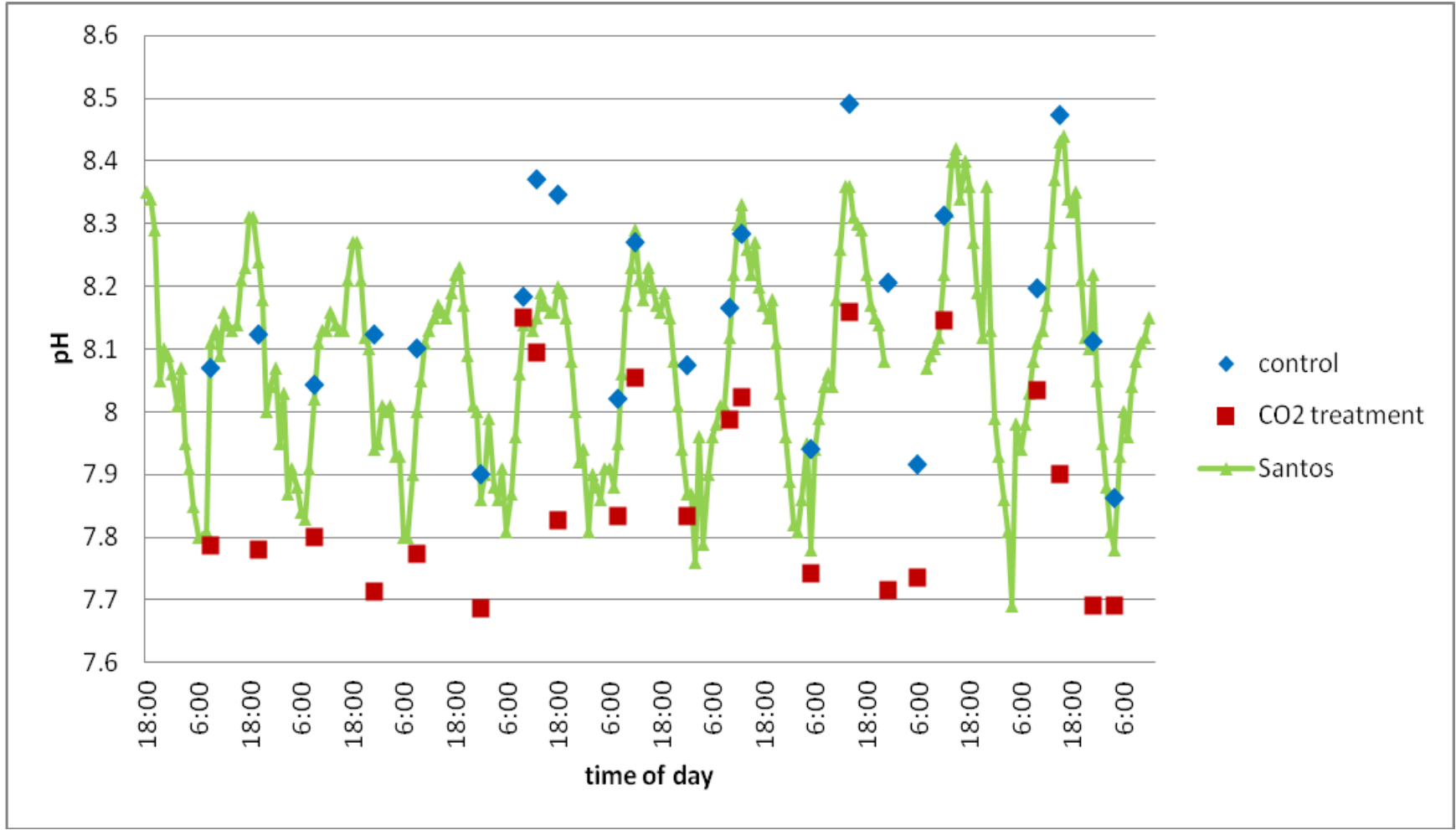

Figure 2: Comparison of $\mathrm{pH}$ data this study to hourly measurements taken from the lagoon for the $5^{\text {th }}$ $12^{\text {th }}$ of December $2009^{31}$. Santos et al. ${ }^{31}$ measured $\mathrm{pH}$ in the lagoon adjacent to the intake pipes sourcing seawater for this study. The control $\mathrm{pH}$ in our study is comparable to the Santos data excepting the extra high $\mathrm{pH}$ recorded on the $8^{\text {th }}$ and $11^{\text {th }}$ of Dec. The $\mathrm{CO}_{2}$ treatment $\mathrm{pH}$ is comparable to the Santos environment for several of the dawn measurements however is well below the environment during the later afternoon. 
Table of results for dissolution

\begin{tabular}{|c|c|c|c|c|c|c|c|c|c|}
\hline $\begin{array}{l}\text { Control } \\
\text { tanks }\end{array}$ & $\begin{array}{c}\mathrm{Mol} \% \\
\mathrm{MgCO}_{3}\end{array}$ & $\begin{array}{c}\text { Asymm } \\
\mathrm{Mol}_{2} \\
\mathrm{MgCO}_{3} \\
\end{array}$ & $\begin{array}{l}\mathrm{Wt} \% \\
\text { Arag }\end{array}$ & $\begin{array}{c}\text { weight } \\
\text { loss }\end{array}$ & tank & $\begin{array}{c}\text { start } \\
\text { weight } \\
\text { (gms) }\end{array}$ & $\begin{array}{c}\text { final } \\
\text { weight } \\
\text { (gms) }\end{array}$ & $\begin{array}{l}\text { Difference } \\
\quad(\mathrm{gms})\end{array}$ & Sub- sample \\
\hline \multicolumn{10}{|c|}{ Dolomite rich group } \\
\hline h301 & $17.96 \%$ & $27.25 \%$ & $0.00 \%$ & $0.11 \%$ & 1 & 2.3405 & 2.3379 & 0.0026 & $\mathrm{q}$ \\
\hline h303 & $17.96 \%$ & $27.25 \%$ & $0.00 \%$ & $0.01 \%$ & 2 & 1.5404 & 1.5402 & 0.0002 & $\mathrm{q}$ \\
\hline h307 & $18.00 \%$ & $27.18 \%$ & $0.00 \%$ & $0.29 \%$ & 1 & 0.518 & 0.5165 & 0.0015 & $\mathrm{q}$ \\
\hline h305 & $*$ & & & $0.27 \%$ & 3 & 1.6032 & 1.5989 & 0.0043 & $q$ \\
\hline Control & $17.88 \%$ & $27.40 \%$ & $0.00 \%$ & & & & & & $\mathrm{q}$ \\
\hline \multicolumn{10}{|c|}{ Average weight loss $0.17 \%$, St.dev $0.13 \%, \mathrm{n}=4$} \\
\hline \multicolumn{10}{|c|}{ Dolomite poor group } \\
\hline h309 & $16.51 \%$ & $17.95 \%$ & $55.63 \%$ & $1.65 \%$ & 1 & 1.1459 & 1.127 & 0.0189 & $\mathrm{r}$ \\
\hline h311** & $16.65 \%$ & $18.96 \%$ & $39.64 \%$ & $1.65 \%$ & 2 & 1.9657 & 1.9332 & 0.0325 & $\mathrm{r}$ \\
\hline h313 & $16.99 \%$ & $18.24 \%$ & $56.85 \%$ & $1.68 \%$ & 3 & 1.3551 & 1.3324 & 0.0227 & $\mathrm{r}$ \\
\hline Control & $16.41 \%$ & $17.71 \%$ & $32.96 \%$ & & & & & & $\mathrm{r}$ \\
\hline h327 & $17.02 \%$ & $19.25 \%$ & $7.62 \%$ & $1.68 \%$ & 3 & 1.4404 & 1.4162 & 0.0242 & $\mathrm{t}$ \\
\hline h321 & $17.00 \%$ & $23.97 \%$ & $0.00 \%$ & $1.70 \%$ & 2 & 1.4753 & 1.4502 & 0.0251 & $\mathrm{~s}$ \\
\hline h317 & $16.31 \%$ & $18.09 \%$ & $31.93 \%$ & $1.77 \%$ & 2 & 2.361 & 2.3191 & 0.0419 & $\mathrm{~s}$ \\
\hline h315 & $17.53 \%$ & $19.53 \%$ & $0.00 \%$ & $2.15 \%$ & 1 & 1.444 & 1.413 & 0.031 & $\mathrm{~s}$ \\
\hline Control & $17.50 \%$ & $18.87 \%$ & $0.00 \%$ & & & & & & $\mathrm{~s}$ \\
\hline h325 & $16.95 \%$ & $19.13 \%$ & $3.80 \%$ & $2.24 \%$ & 2 & 4.2547 & 4.1594 & 0.0953 & $\mathrm{t}$ \\
\hline h323 & $16.99 \%$ & $19.90 \%$ & $6.18 \%$ & $2.26 \%$ & 1 & 5.3147 & 5.1944 & 0.1203 & $\mathrm{t}$ \\
\hline Control & $17.08 \%$ & $18.47 \%$ & $15.25 \%$ & & & & & & $\mathrm{t}$ \\
\hline \multicolumn{10}{|c|}{ Average weight loss $1.89 \%$, St. dev $0.28 \%, \mathrm{n}=9$} \\
\hline \multicolumn{10}{|c|}{ High $\mathrm{CO}_{2}$ tanks } \\
\hline \multicolumn{10}{|c|}{ Dolomite rich group } \\
\hline h302 & $17.77 \%$ & $26.40 \%$ & $0.00 \%$ & $0.30 \%$ & 4 & 2.0281 & 2.022 & 0.0061 & $\mathrm{q}$ \\
\hline h304 & $17.90 \%$ & $26.28 \%$ & $0.00 \%$ & $0.39 \%$ & 5 & 1.3195 & 1.3144 & 0.0051 & $\mathrm{q}$ \\
\hline h308 & $17.25 \%$ & $26.74 \%$ & $0.00 \%$ & $0.64 \%$ & 4 & 1.225 & 1.2171 & 0.0079 & $\mathrm{q}$ \\
\hline h306 & $17.67 \%$ & $28.24 \%$ & $0.00 \%$ & $0.69 \%$ & 6 & 1.3505 & 1.3412 & 0.0093 & $\mathrm{q}$ \\
\hline \multicolumn{10}{|c|}{ Average weight loss $0.51 \%$, St. dev $0.19 \%, \mathrm{n}=4$} \\
\hline \multicolumn{10}{|c|}{ Dolomite poor group } \\
\hline h324 & $16.46 \%$ & $18.20 \%$ & $8.85 \%$ & $2.01 \%$ & 4 & 2.8279 & 2.7711 & 0.0568 & $\mathrm{t}$ \\
\hline h314 & $17.08 \%$ & $20.17 \%$ & $5.51 \%$ & $2.46 \%$ & 6 & 1.2627 & 1.2316 & 0.0311 & $\mathrm{r}$ \\
\hline h318 & $17.43 \%$ & $21.09 \%$ & $0.00 \%$ & $2.47 \%$ & 5 & 2.0603 & 2.0094 & 0.0509 & $\mathrm{~s}$ \\
\hline h310 & $17.23 \%$ & $19.91 \%$ & $4.92 \%$ & $2.59 \%$ & 4 & 1.0945 & 1.0662 & 0.0283 & $\mathrm{r}$ \\
\hline h316 & $17.25 \%$ & $19.24 \%$ & $4.74 \%$ & $2.75 \%$ & 4 & 1.6714 & 1.6254 & 0.046 & $\mathrm{~s}$ \\
\hline h320*** & $16.79 \%$ & $23.22 \%$ & $0.00 \%$ & $3.42 \%$ & 6 & 1.0202 & 0.9853 & 0.0349 & $\mathrm{~s}$ \\
\hline h312 & $17.01 \%$ & $19.02 \%$ & $53.77 \%$ & $4.25 \%$ & 5 & 1.2554 & 1.2021 & 0.0533 & $\mathrm{r}$ \\
\hline h326 & $16.59 \%$ & $19.12 \%$ & $13.39 \%$ & $4.54 \%$ & 5 & 1.0304 & 0.9836 & 0.0468 & $\mathrm{t}$ \\
\hline \multicolumn{10}{|c|}{ Average weight loss $3.06 \%$, St. dev $0.92 \%, \mathrm{n}=8$} \\
\hline
\end{tabular}


Table 3a: Dissolution experiment results and mineralogy. $\mathrm{Mol} \% \mathrm{MgCO}_{3}$ determined according to ${ }^{32}$. Asymm. $\mathrm{Mol} \% \mathrm{MgCO}_{3}$ determined according to M.C.N. et al. (manuscript in preparation). Aragonite $\%$ determined using area under the curve method ${ }^{33}$. Samples with the least weight loss typically had no aragonite, but there is no clear trend with aragonite and weight loss in the remainder of the group. *subsample kept intact for SEM, mineralogy matched other q subsamples. **Assessed as $\mathrm{D}^{\mathrm{p}}$ by XRD, confirmed in SEM, magnesite also detected in one cell layer however not detectable in XRD (Fig. 5 SI). *** The XRD line lay between the dolomite rich and dolomite poor lines in the dolomite range however crossed into the magnesite shoulder. SEM showed this sample had bands of dolomite rich and dolomite poor layers and was without substantial cell in-fill (Fig. 10 SI). Sample letter refers to the piece of crust which they were broken from. Control is the dry subsample kept from each crust and did not go into tanks. Quantification of dolomite has not been determined as typical methods using curve fitting programs rely on single peaks and the dolomite in the CCA ranges from 38 - 62 mol\% $\mathrm{MgCO}_{3}$ resulting in a continuum on the XRD trace making quantification by determining the area under the curve problematic.

Table 3b statistics

\begin{tabular}{|c|c|c|c|c|c|c|}
\hline & Line & $\mathrm{R}$ & $\mathrm{R}^{2}$ & $\begin{array}{l}\mathrm{P} \text { value } \\
2 \text { tailed } \\
\text { test }\end{array}$ & $\mathrm{df}$ & error \\
\hline $\begin{array}{l}\text { Control } \\
\mathrm{mol} \%\end{array}$ & $y=-1.0483 x+0.1941$ & -0.74 & 0.55 & 0.01 & 9 & 0.00257 \\
\hline $\begin{array}{l}\text { Control } \\
\text { Asymm. } \\
\text { mol\% }\end{array}$ & $y=-0.1871 x+0.0545$ & -0.87 & 0.76 & 0.01 & 9 & 0.00257 \\
\hline $\begin{array}{l}\text { High } \mathrm{CO}_{2} \\
\mathrm{~mol} \%\end{array}$ & $y=-2.2382 x+0.4076$ & -0.69 & 0.48 & 0.02 & 9 & 0.004357 \\
\hline $\begin{array}{l}\text { High } \mathrm{CO}_{2} \\
\text { Asymm. } \\
\text { mol\% }\end{array}$ & $y=-0.3384 x+0.0971$ & -0.77 & 0.60 & 0.01 & 9 & 0.004357 \\
\hline
\end{tabular}

Statistics summary for Figure 1a and 1c main text. Between control and high $\mathrm{CO}_{2}$, the gradients for the $\mathrm{mol} \%$ and Asymm. mol\% are significantly different, $\mathrm{p}=0.03(\mathrm{~mol} \%) \mathrm{p}=0.0038$ (Asymm), $\mathrm{df}$ $=21$. The differences in mass loss for the dolomite rich and dolomite poor samples are significant for both control and high $\mathrm{CO} 2, \mathrm{p}<0.001$ for both. 


\section{Methods for calculating $\mathrm{Mol} \% \mathrm{MgCO}_{3}$ for asymmetrical XRD Mg-Calcite peaks}

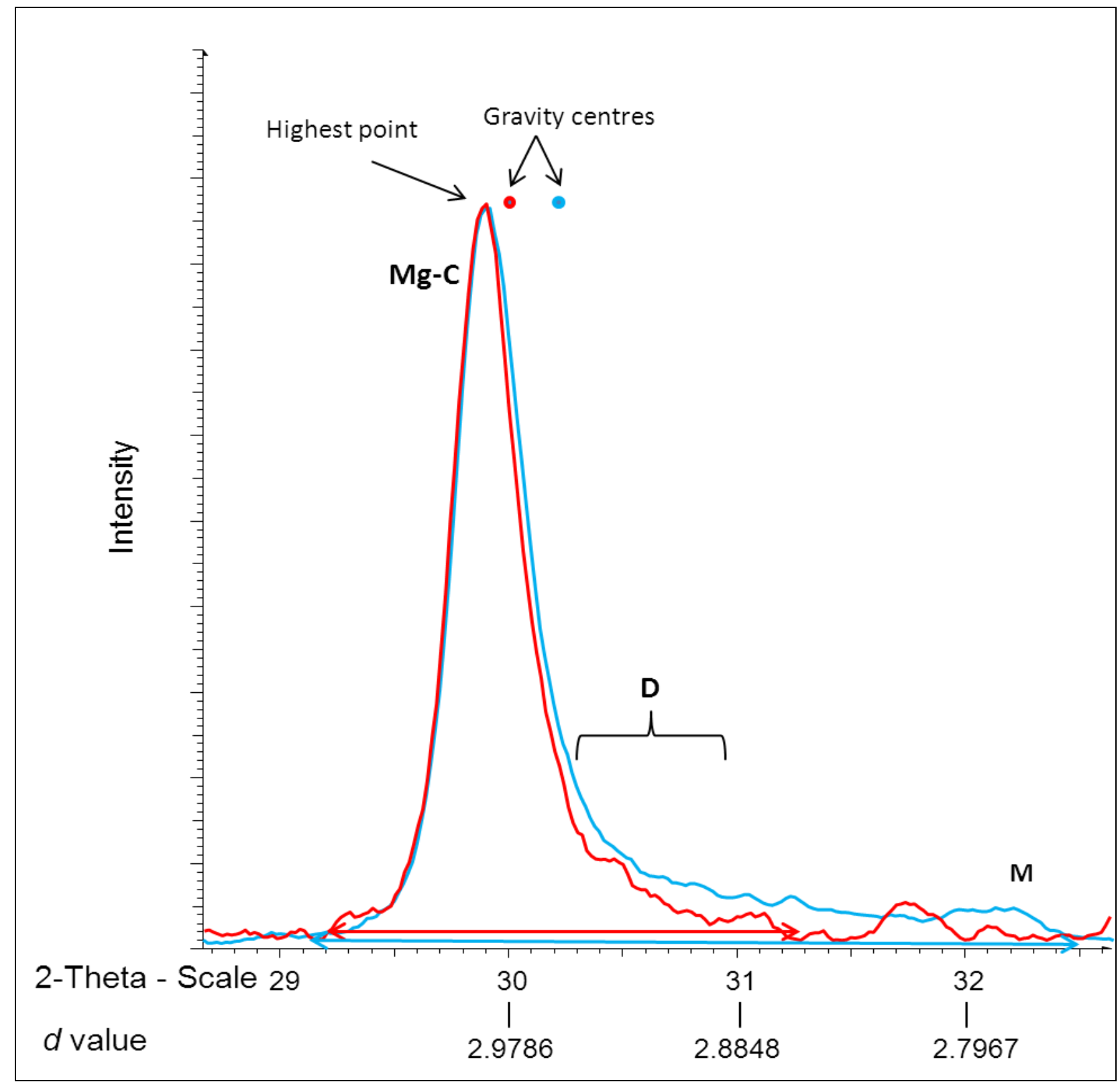

Figure 3: Xray diffraction peak selection for asymmetry mol\% $\mathrm{MgCO}_{3}$. Red curve CCA H311 $\left(\mathrm{D}^{\mathrm{p}}\right)$, aqua curve CCA H308 ( $\left.\mathrm{D}^{\mathrm{r}}\right)$. Mg-C Mg-calcite peak, D dolomite range (M.C.N. et al., manuscript in preparation), M magnesite. The usual method for selecting the peak position $d$-value to use in a mol\% calibration equation is to select the highest point of the curve and use the $d$-value at this position. For these two curves the highest points are nearly aligned and the mol\% for the $d$-values are $\mathrm{D}^{\mathrm{p}}=16.65$ and $\mathrm{D}^{\mathrm{r}}=17.25 \mathrm{~mol} \% \mathrm{MgCO}_{3}$. If this was the only information used to compare samples then the conclusion may be erroneously drawn that the mineralogy is similar, however the asymmetry of the curves is clearly substantially different. The XRD scan processing program we used, EVA Diffrac 
Plus, has a function to calculate the centre of gravity of a curve (done by using the area function to take a line across the base of the curve - the arrows in this figure- this returns both the area under the curve and the gravity centre). The gravity centre peak position is calculated by the program using the mean of each measurement interval weighted by the net intensity. The result is a gravity centre peak position skewed by the asymmetry, and simply, the more asymmetry then the further right (higher 2theta, lower $d$-value) of the highest point the gravity centre is located. Thus in this example the $\mathrm{D}^{\mathrm{r}}$ sample, visibly strongly asymmetrical, has a gravity centre peak further right (towards lower $d$-value which results in a higher calculated $\mathrm{mol} \% \mathrm{MgCO}_{3}$ ) than the $\mathrm{D}_{\mathrm{p}} \mathrm{CCA}$. The asymmetry mol\% (calculated from the $d$-value at the gravity centre) is $26.74 \mathrm{~mol} \% \mathrm{MgCO}_{3}$, whereas the asymmetry $\mathrm{mol} \%$ for the Dp CCA is only $18.96 \mathrm{~mol} \% \mathrm{MgCO}_{3}$. Note the asymmetry mol\% is not an average $\mathrm{mol} \% \mathrm{MgCO}_{3}$ for the magnesium in all the minerals (when there is dolomite and /or magnesite present). The asymmetry mol\% is a quick, reproducible, numerical representation of the curve asymmetry resulting from the presence of higher magnesium carbonates, dolomite and magnesite. The mineralogy of these two samples was confirmed by SEM-EDS.

Gridded point count of base 100 microns in Fig. 3

\begin{tabular}{|l|l|l|}
\hline Type & Dolomite rich (H302) & Dolomite poor (H56) \\
\hline Dolomite & $14.8 \%$ & Not detected \\
\hline Mg-calcite cell wall & Not detected & $31.2 \%$ \\
\hline Inter-cell Mg-calcite & $58.0 \%$ & $1.6 \%$ \\
\hline Intra-cell Mg-calcite & $20.6 \%$ & $2.6 \%$ \\
\hline Inter-cell space & $3.0 \%$ & $9.0 \%$ \\
\hline Intra-cell space & $3.7 \%$ & $55.6 \%$ \\
\hline Aragonite & Not detected & Not detected \\
\hline Total & $100 \%$ & $100 \%$ \\
\hline
\end{tabular}

Table 4: Mapping- H302 4 lines down and 4 across, H56 4 lines down, 3 across, approximately 30 microns apart. Percentage is linear distance for each category above. 


\section{Additional SEM images}
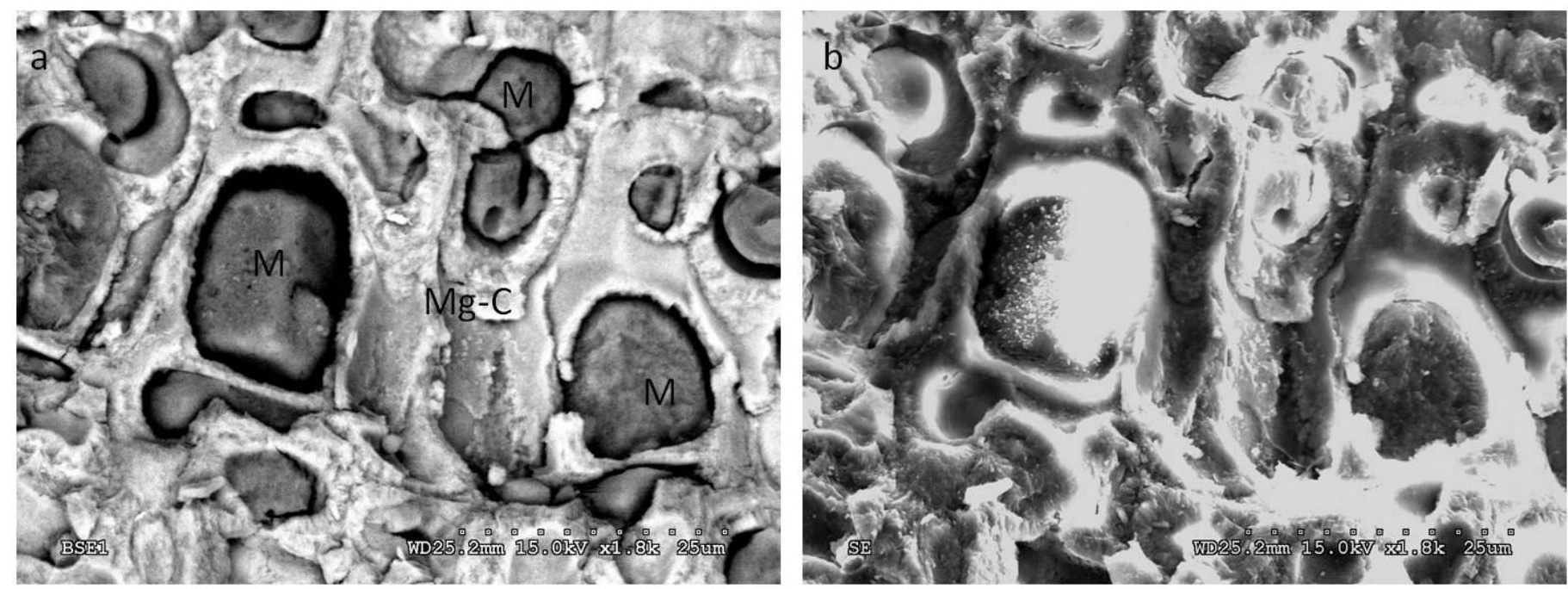

Figure 4: Magnesite (M) in cell spaces of $D^{p}$ CCA H311. a Back-scatter electron image, b

secondary electron image. This magnesite was not detected in the XRD analysis and only one patch was found in the sample. There are no dolomite rims, however the perimeter where the dolomite rims are usually found is void (black in BSE). This suggests that the mineralization processes forming dolomite and magnesite are independent. Mg-calcite (Mg-C).
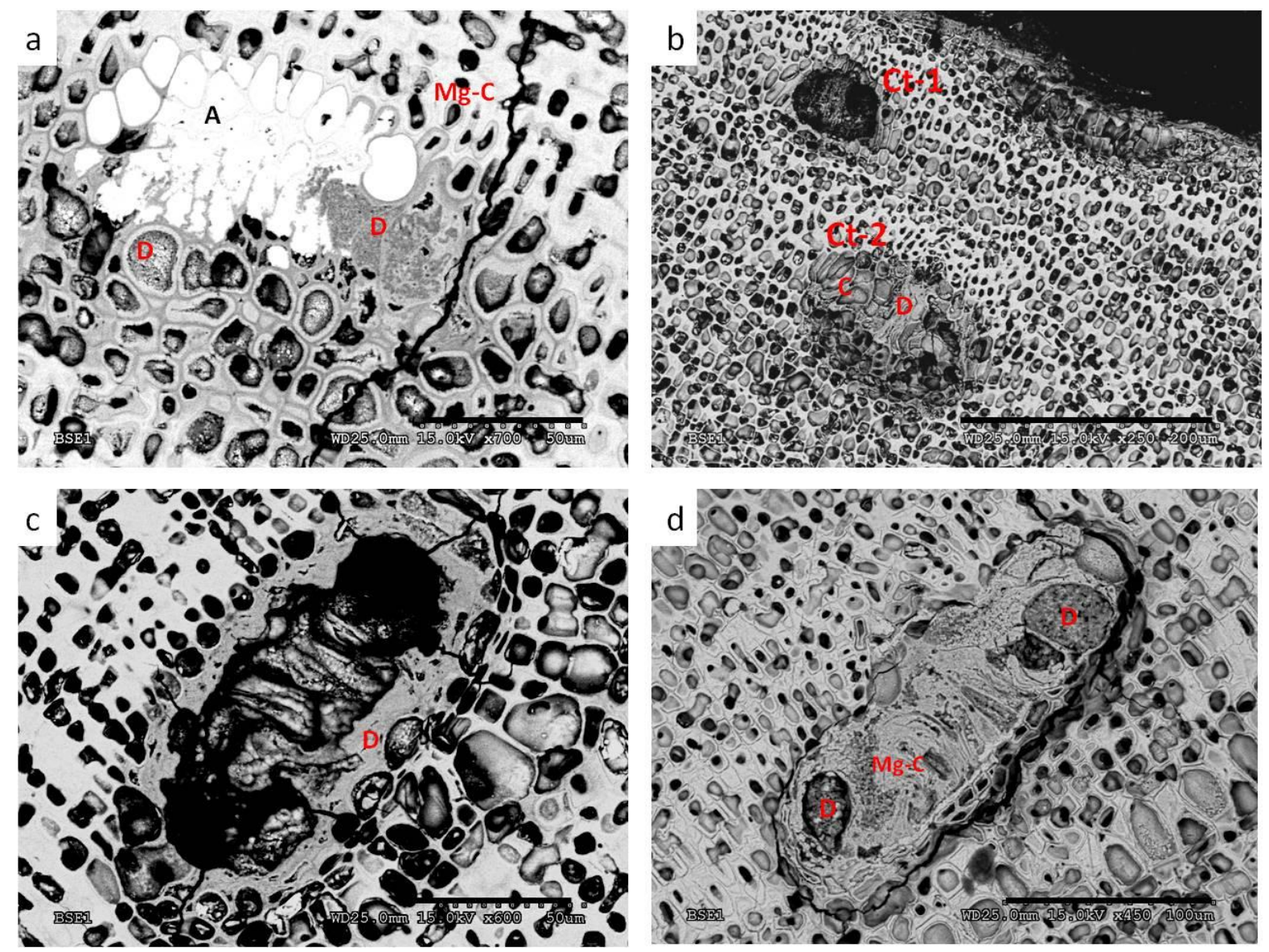
Figure 5: Differing conceptacle mineral in-fill in $D^{p} H 56$. a cell re-growth in conceptacle, partially dolomite (D), cell spaces filled by aragonite (A), scale $50 \mu \mathrm{m}$. b Conceptacle 1 (Ct-1) near surface with partial cell re-growth, $\mathrm{Mg}$-calcite, Conceptacle $2(\mathrm{Ct}-2)$ has dolomite pillar in the conceptacle centre and Mg-calcite (C) cells, scale $200 \mu \mathrm{m}$. c conceptacle rimmed by dolomite and dolomite in the centre, scale $50 \mu \mathrm{m}$. d partial $\mathrm{Mg}$-calcite cell re-growth visible in centre, dolomite appears to have nucleated on organic fabric, scale $100 \mu \mathrm{m}$.
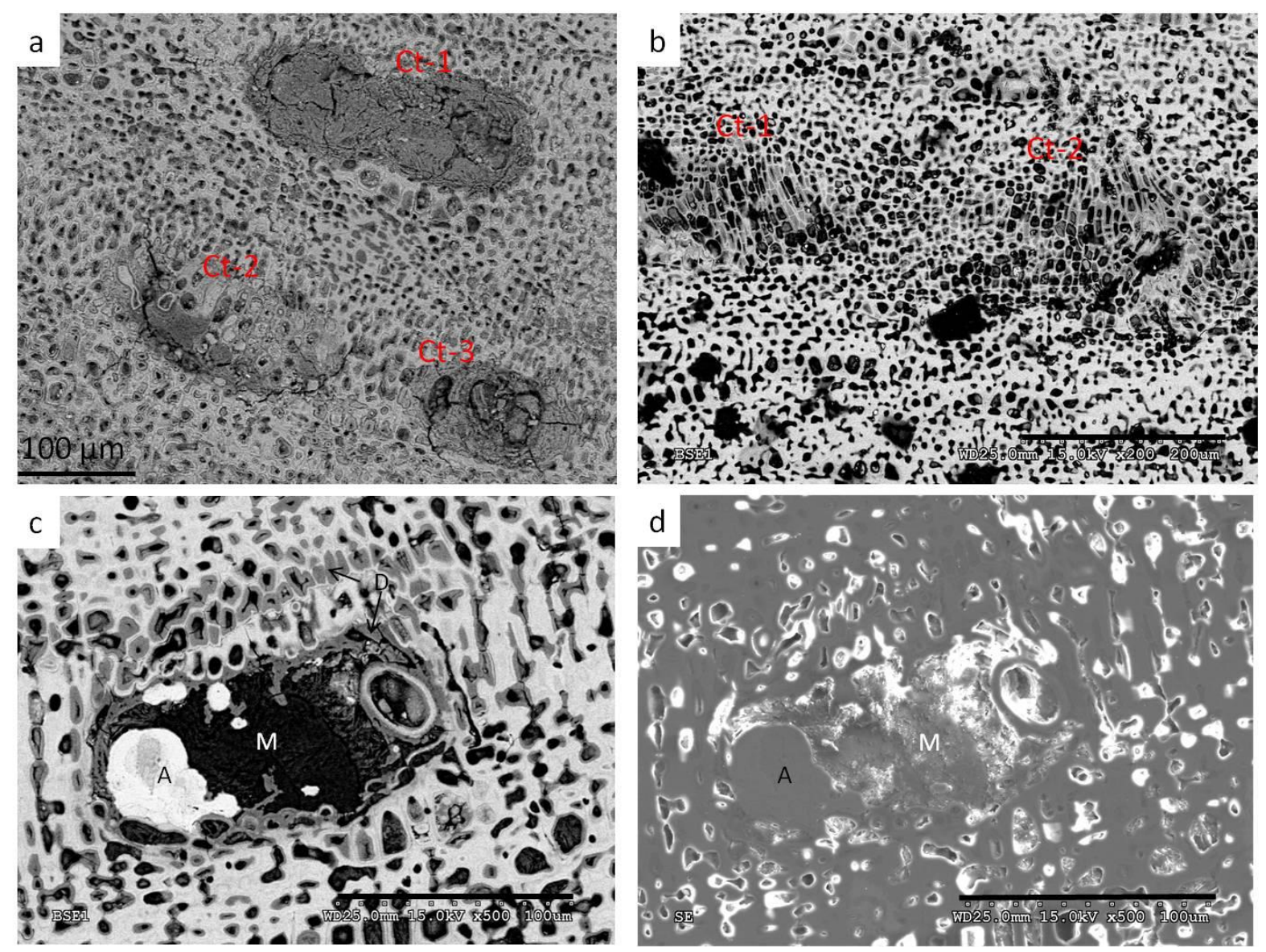

Figure 6: conceptacle mineral in-fill in $\mathrm{D}^{\mathrm{r}}$. a CCA H302 Conceptacle 1 (Ct-1) in-filled by magnesite, Conceptacle 2 partial cell re-growth, conceptacle 3 dolomite in-fill (after $2^{\text {nd }}$ etching). b Cell regrowth in conceptacle 1 and 2 (before etching). Cells are dolomite (grey), scale $200 \mu \mathrm{m}$. c CCA H47 Magnesite and aragonite in-filling conceptacle, scale $100 \mu \mathrm{m}$. d secondary electron image of c, aragonite is a smooth cement whereas magnesite is coarse. White is charging indicating empty space. scale $100 \mu \mathrm{m}$. 


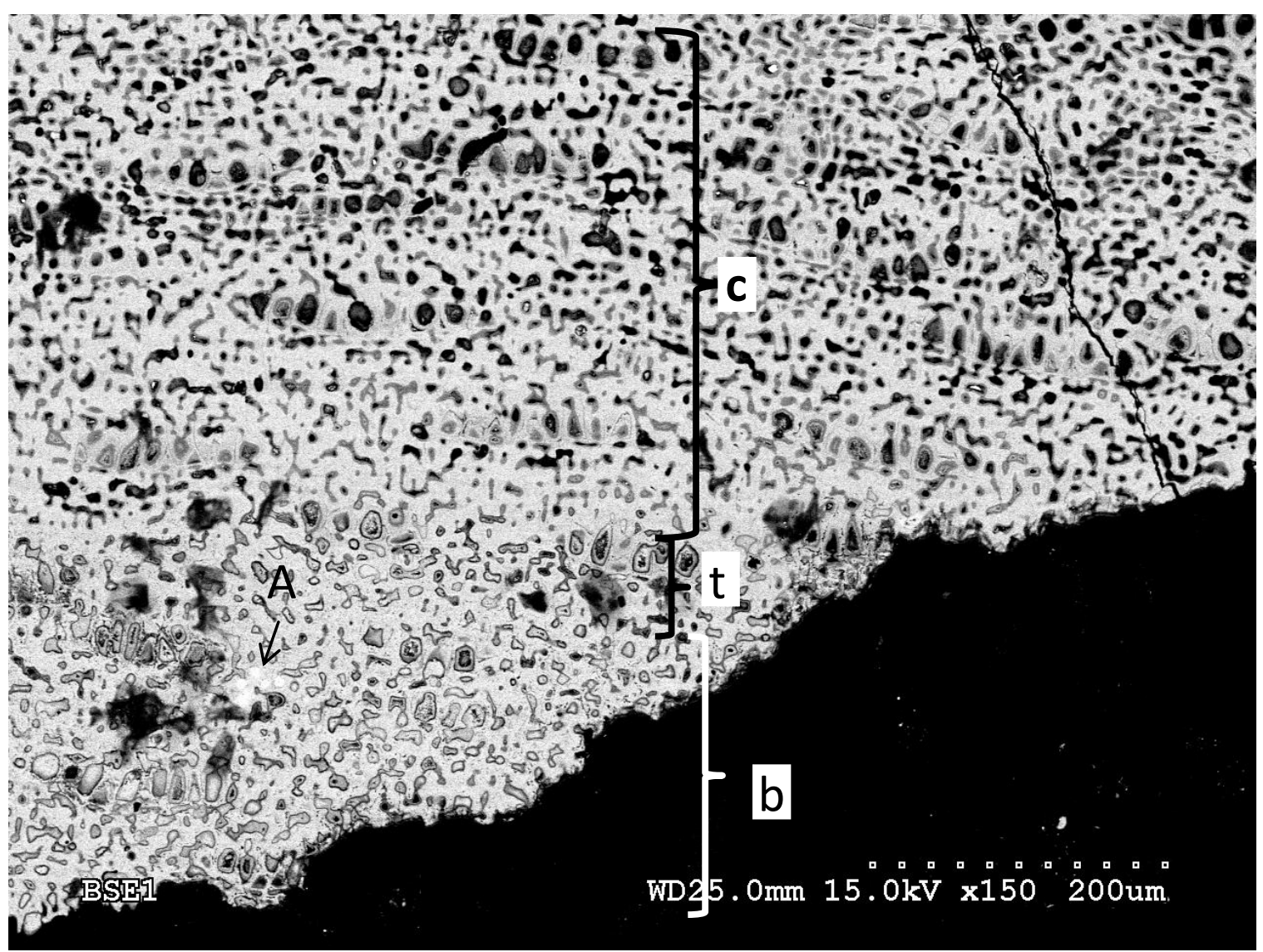

Figure 7: Transition from main crust to exposed base layers in dolomite rich coralline (H302). The main crust (c) has magnesite, dolomite and Mg-calcite, the base layers (b) have only dolomite rims and Mg-calcite. There are also small patches of aragonite (A - white). The base $\sim 400-600$ microns in both types of coralline algae show alteration indicating that this is the typical penetration of seawater into the lower crust. The transition in this sample takes place over 50-60 microns (t) suggesting the process is relatively rapid. 


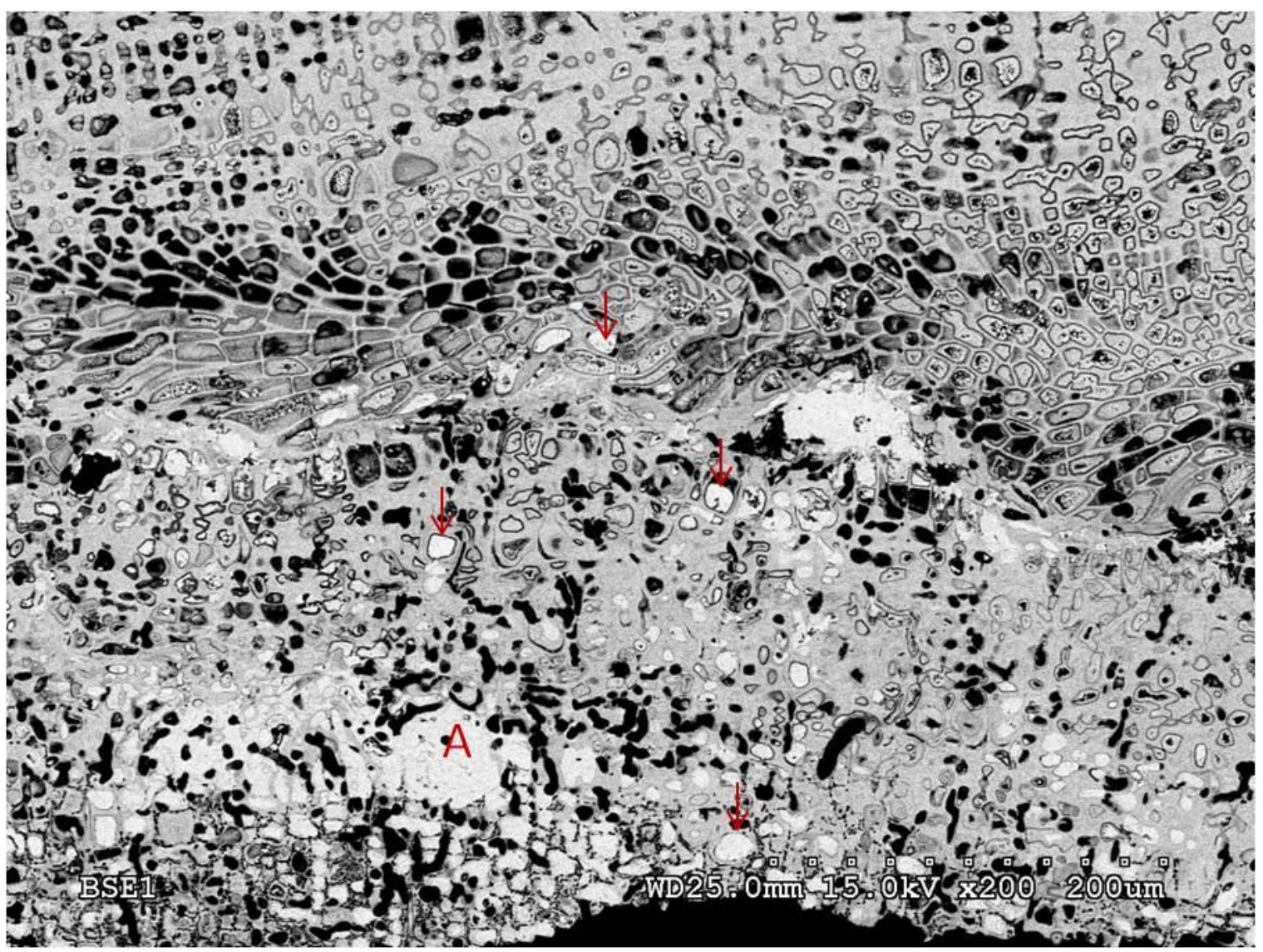

Figure 8: Aragonite cell in-fill and crust replacement in base layers of dolomite rich coralline (Sample P.onkodes H47). Cell in-fill by aragonite (arrows), fabric destructive replacement by aragonite (A). Dolomite rims remain in the lower layers as does Mg-calcite cell wall however there is no magnesite. Typically in the dolomite rich samples aragonite was detected in the base layers and proximal to holes in the main crust, presenting as both discrete cell replacement, usually with the dolomite rims preserved and fabric destructive patches. This suggests a diagenetic process that transforms unstable mineralogy, i.e. Mg-calcite, and magnesite to aragonite or in-fills non-mineralised spaces.
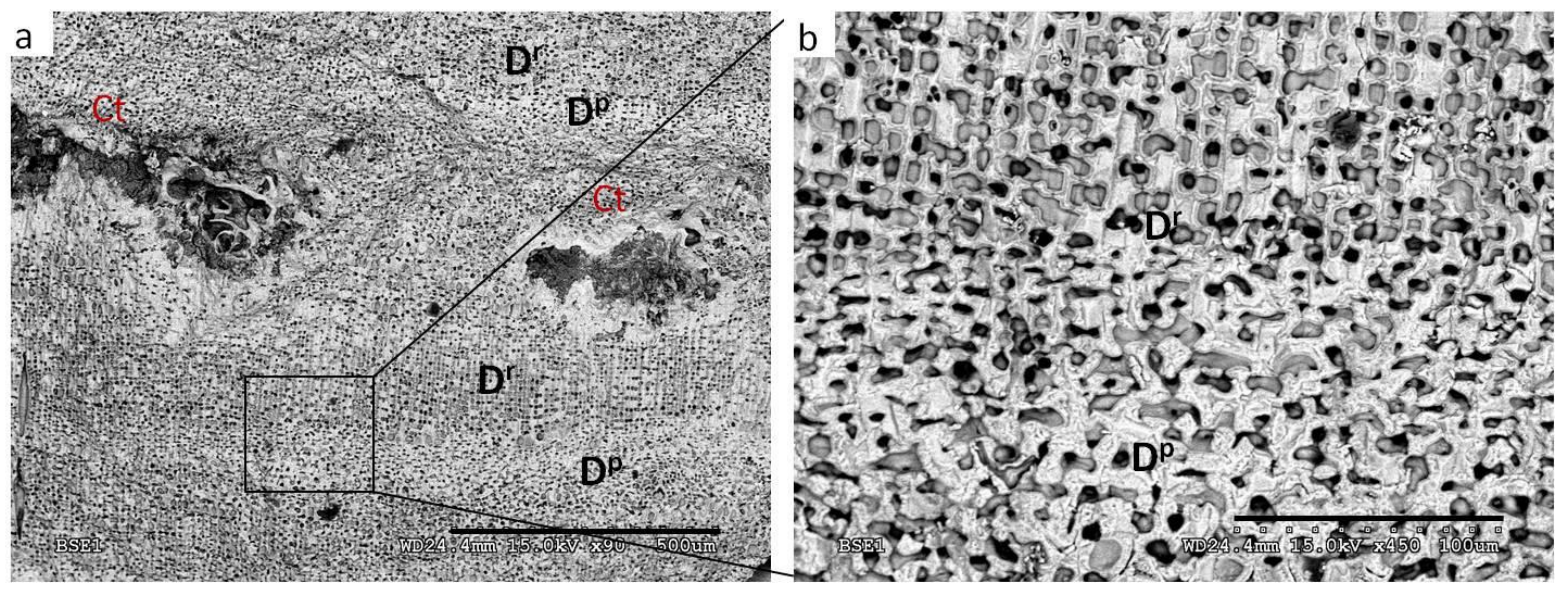

Figure 9: Bands of dolomite rich and dolomite poor layers in H320. The XRD scan line lay between that for $\mathrm{D}^{\mathrm{p}}$ and $\mathrm{D}^{\mathrm{r}}$ in the dolomite range however formed a low shoulder towards magnesite. $\mathbf{a}$ 
conceptacles filled with magnesite and rimmed by $\mathrm{Mg}$-calcite. Banding of dolomite rims suggests a seasonal influence on formation, scale $500 \mu \mathrm{m}$. b enlargement showing $\mathrm{D}^{\mathrm{p}}$ with thicker inter-filament areas and thin or no dolomite rims and $\mathrm{D}^{\mathrm{r}}$ less inter-filament $\mathrm{Mg}$-calcite and thicker dolomite rims, scale $100 \mu \mathrm{m}$.

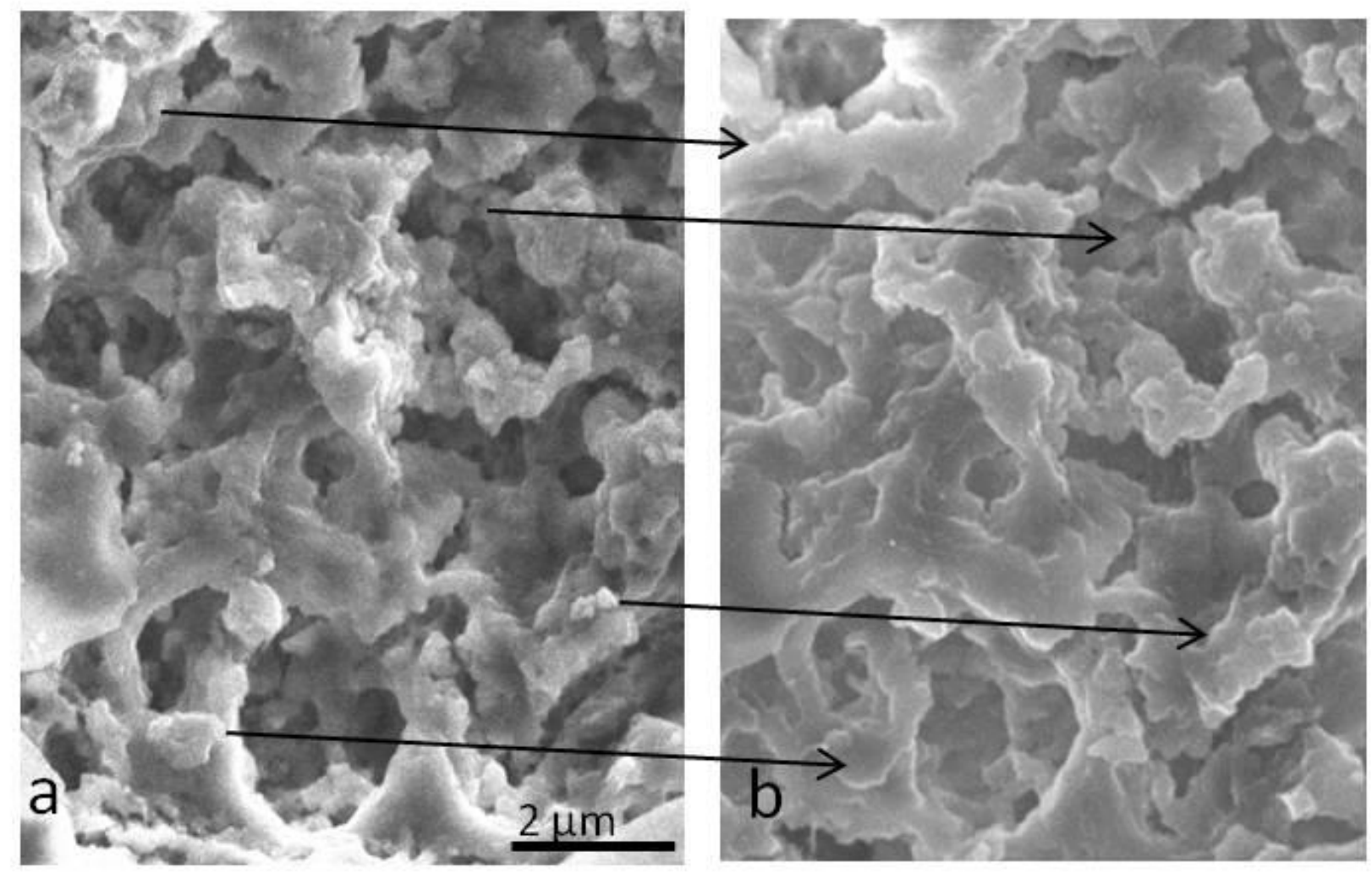

Figure 10: Dissolution of dolomite in conceptacles after etching. a after 1 hour etching, sub-micron grains of dolomite (composition confirmed by SEM-EDS) on organic framework in conceptacle. $\mathbf{b}$ after 6 hours etching dolomite grains removed (arrows) and conceptacle interior framework is more translucent. Contrast settings are not the same for both pictures as contrast is adjusted throughout the SEM session depending on distance and focus settings. 

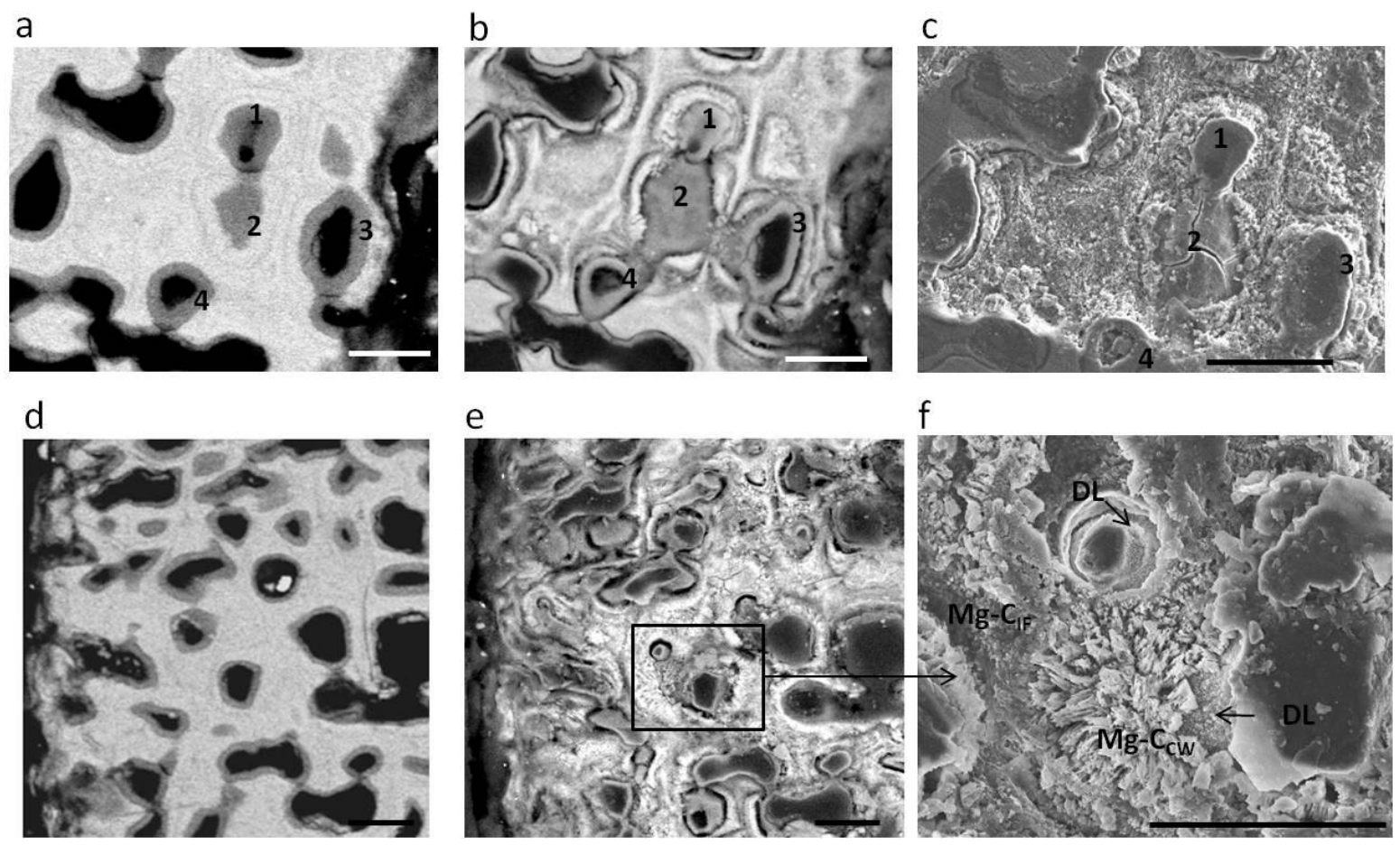

Figure 11: Progressive etching experiment of dolomite rich coralline algae (H302). a and d, Back scattered electron image of polished $\mathrm{D}^{\mathrm{r}} \mathrm{CCA}$ section prior to etching, light grey to white - Mg-calcite, grey - dolomite, dark grey to black - void. b is a etched $1 \mathrm{hr}$, ph 8 . Mg-calcite removed to expose dolomite cell fusion between 2-3 and 2-4. c Secondary electron image of $\mathbf{b}$, cell wall Mg-calcite is prominent around the edges of dolomite rims and inter-filament $\mathrm{Mg}$-calcite is depleted. Crack in dolomite at 2 caused by multiple EDS measurements. e Is d etched 6 hrs, pH 7.7-7.8. Mg-calcite has been preferentially removed, leaving dolomite cell shapes in relief. f Secondary electron image enlargement of $\mathbf{e}$, showing that inter-filament $\mathrm{Mg}$-calcite $\left(\mathrm{Mg}-\mathrm{C}_{\mathrm{IF}}\right)$ was removed. Cell wall $\mathrm{Mg}$-calcite $\left(\mathrm{Mg}-\mathrm{C}_{\mathrm{cw}}\right)$ crystals appear to be attached perpendicular to the dolomite lining underneath. Dolomite crystals on the exterior of the cell lining are nano-scale. scale bars $10 \mu \mathrm{m}$. 


\section{Summary table of mineralogy (present study)}

\begin{tabular}{|c|c|c|c|c|c|c|c|c|c|c|}
\hline Location & Location & Environment & Species & 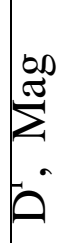 & 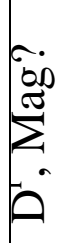 & A & $\begin{array}{l}\hat{\nabla} \\
\hat{v} \\
\hat{\theta}\end{array}$ & คُ & 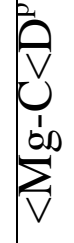 & 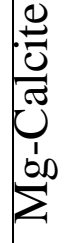 \\
\hline \multirow{4}{*}{$\begin{array}{l}\text { Caribbean } \\
\text { (collected } \\
1972 \text { ) }\end{array}$} & St. Croix & Algal Ridge, intertidal & $\begin{array}{l}\text { Porolithon } \\
\text { Pachydermum }\end{array}$ & & & & & $\mathrm{X}$ & & \\
\hline & $\begin{array}{l}\text { Virgin } \\
\text { Gorda }\end{array}$ & Reef flat, $1 \mathrm{~m}$ & $\begin{array}{l}P . \\
\text { Pachydermum }\end{array}$ & & & & & & & $X$ \\
\hline & St. Croix & Acropora reef, $3-10 \mathrm{~m}$ & $\begin{array}{l}P . \\
\text { Pachydermum }\end{array}$ & $\mathrm{X}$ & & & & & & \\
\hline & St. Thomas & $\begin{array}{l}\text { Rocky ground, CCA } \\
\text { covered, } 0-3 \mathrm{~m}\end{array}$ & $\begin{array}{l}P . \\
\text { Pachydermum }\end{array}$ & & $\begin{array}{l}\mathrm{X} \\
*\end{array}$ & & & & & \\
\hline $\begin{array}{l}\text { Papua New } \\
\text { Guinea }\end{array}$ & Ily Ily & $\sim 0-5 \mathrm{~m}$ & P. onkodes & & & $\begin{array}{l}\mathrm{X} \\
* \\
\end{array}$ & & $X$ & & \\
\hline \multirow{12}{*}{$\begin{array}{l}\text { Japan, } \\
\text { Ryukyu } \\
\text { Islands }\end{array}$} & $\begin{array}{l}\text { Okinawaji } \\
\text { ma Island }\end{array}$ & $<5 \mathrm{~m}$ & P. onkodes & $\mathrm{X}$ & $\mathrm{X}$ & & & $\mathrm{X}$ & & $\mathrm{X}$ \\
\hline & $\begin{array}{l}\text { Ishigaki } \\
\text { Island }\end{array}$ & $<5 \mathrm{~m}$ & $\begin{array}{l}\text { Pneophyllum } \\
\text { conicum }\end{array}$ & & & & & $\mathrm{X}$ & & \\
\hline & $\begin{array}{l}\text { Ishigaki } \\
\text { Island }\end{array}$ & $<5 \mathrm{~m}$ & $\begin{array}{l}\text { Mesophyllum } \\
\text { erubescens }\end{array}$ & & & & & $\mathrm{X}$ & & \\
\hline & $\begin{array}{l}\text { Okinoerabu } \\
\text { Island }\end{array}$ & $<5 \mathrm{~m}$ & P. onkodes & & & $\mathrm{X}$ & & $\mathrm{X}$ & & \\
\hline & $\begin{array}{l}\text { Okinawaji } \\
\text { ma Island }\end{array}$ & $<5 \mathrm{~m}$ & $\begin{array}{l}\text { Neogoniolithon } \\
\text { megalocystum }\end{array}$ & & & & $X$ & & & \\
\hline & $\begin{array}{l}\text { Okinawaji } \\
\text { ma Island }\end{array}$ & $<5 \mathrm{~m}$ & $\begin{array}{l}\text { Lithophyllum } \\
\text { kotschyanum }\end{array}$ & & & $\begin{array}{l}\mathrm{X} \\
* \\
* \\
\end{array}$ & $\mathrm{X}$ & & & \\
\hline & $\begin{array}{l}\text { Okinoerabu } \\
\text { Island }\end{array}$ & $<5 \mathrm{~m}$ & L. insipidium & & & & $\mathrm{X}$ & & & \\
\hline & $\begin{array}{l}\text { Okinawaji } \\
\text { ma Island }\end{array}$ & $<5 \mathrm{~m}$ & P. conicum & & & ? & $X$ & $?$ & & \\
\hline & $\begin{array}{l}\text { Okinawaji } \\
\text { ma Island }\end{array}$ & micro-atoll at moat & $\begin{array}{l}\text { Hydrolithon } \\
\text { reinboldii }\end{array}$ & & & & & & & $\mathrm{X}$ \\
\hline & $\begin{array}{l}\text { Okinoerabu } \\
\text { Island }\end{array}$ & $<5 \mathrm{~m}$ & $\begin{array}{l}\text { N. brassica- } \\
\text { florida }\end{array}$ & & & & & & & $\mathrm{X}$ \\
\hline & $\begin{array}{l}\text { Okinawaji } \\
\text { ma Island }\end{array}$ & $<5 \mathrm{~m}$ & $\begin{array}{l}\text { Mastophora } \\
\text { rosea }\end{array}$ & & & & & & & $\mathrm{X}$ \\
\hline & $\begin{array}{l}\text { Okinoerabu } \\
\text { Island }\end{array}$ & $<5 \mathrm{~m}$ & P. conicum & & & & & & $X$ & \\
\hline \multirow{4}{*}{$\begin{array}{l}\text { Great } \\
\text { Barrier } \\
\text { Reef }\end{array}$} & $\begin{array}{l}\text { Lizard } \\
\text { Island }\end{array}$ & & P. onkodes & & & $\begin{array}{l}\mathrm{X} \\
*\end{array}$ & & & & \\
\hline & $\begin{array}{l}\text { Heron } \\
\text { Island }\end{array}$ & $<5 \mathrm{~m}$ to reef crest & P.onkodes & $\begin{array}{l}\mathrm{X} \\
*\end{array}$ & $\mathrm{X}$ & $\mathrm{X}$ & $\begin{array}{l}\mathrm{X} \\
* * \\
\end{array}$ & $\begin{array}{l}\mathrm{X} \\
*\end{array}$ & & $\mathrm{X}$ \\
\hline & $\begin{array}{l}\text { Heron } \\
\text { Island }\end{array}$ & Reef crest & L. mustard & & & & & $\begin{array}{l}\mathrm{X} \\
*\end{array}$ & & \\
\hline & $\begin{array}{l}\text { Heron } \\
\text { Island Core }\end{array}$ & $\begin{array}{l}\text { Windward reef front } \\
\text { core }-20 \mathrm{~cm}, 5.6 \mathrm{~m} \text { down } \\
\text { core }\end{array}$ & $\begin{array}{l}\text { 1cm thick } \\
\text { crust (not } \\
\text { dated) }\end{array}$ & & & & & $\mathrm{X}$ & & \\
\hline
\end{tabular}




\begin{tabular}{|c|c|c|c|c|c|c|c|}
\hline \multirow[t]{2}{*}{$\begin{array}{l}\text { Rodrigues, } \\
\text { Indian } \\
\text { Ocean }\end{array}$} & $\begin{array}{l}\text { Rodrigues } \\
\text { Core }\end{array}$ & $\begin{array}{l}\text { Windward algal ridge } \\
\text { core }-35 \mathrm{~cm}, 3.2 \mathrm{~m} \text { down } \\
\text { core }\end{array}$ & $\begin{array}{l}\sim 1 \text { cm thick } \\
\text { crust }(290, \\
2666 \text { yrs })\end{array}$ & $X$ & & & \\
\hline & $\begin{array}{l}\text { Rodrigues } \\
\text { core }\end{array}$ & $\begin{array}{l}\text { Windward algal ridge } \\
\text { core }-50 \mathrm{~cm}, 80 \mathrm{~cm} \text {, } \\
\text { down core }\end{array}$ & $\begin{array}{l}\sim 1 \mathrm{~cm} \text { thick } \\
\text { crust }(\sim 417, \\
667 y \text { rs }\end{array}$ & & $?$ & $\mathrm{X}$ & \\
\hline Bermuda & & cup reefs & $\begin{array}{l}\text { Neogoniolithon } \\
\text { sp. }\end{array}$ & & & & $\mathrm{X}$ \\
\hline $\begin{array}{l}\text { New South } \\
\text { Wales }\end{array}$ & Merimbula & tidal pool & ?articulated & & & & $\mathrm{X}$ \\
\hline $\begin{array}{l}\text { South } \\
\text { Australia }\end{array}$ & $\begin{array}{l}\text { Adelaide, } \\
\text { Encounter } \\
\text { Bay }\end{array}$ & $0.5 \mathrm{~m}$ & $?$ & & & & $X$ \\
\hline \multirow[t]{3}{*}{ Victoria } & $\begin{array}{l}\text { Point } \\
\text { Westall }\end{array}$ & $\begin{array}{l}2-3 \mathrm{~m} \text {, on rocks, } \\
\text { rhodoliths }\end{array}$ & $\begin{array}{l}\text { Neogoniolithon } \\
\text { brassica - } \\
\text { florida. }\end{array}$ & & & & $X$ \\
\hline & “ & “ & Lithothamnion & & & & $X$ \\
\hline & “ & “ & $?$ & & & & $X$ \\
\hline
\end{tabular}

Table 5: Summary of mineralogy for samples analysed by XRD. This table is a summary of 147 samples analysed by us (includes samples referred to in refs. 30, 34). Classification was made by comparing the XRD scan to a scan of a CCA with mineralogy confirmed by SEM for each of the; Dolomite rims plus magnesite $\left(\mathrm{D}^{\mathrm{r}}, \mathrm{Mag}\right)$, Dolomite rims $\left(\mathrm{D}^{\mathrm{r}}\right), \mathrm{Mg}$-calcite and dolomite conceptacles $\left(\mathrm{D}^{\mathrm{p}}\right), \mathrm{Mg}$-calcite only $(\mathrm{Mg}-\mathrm{C})$. Where identification was between $\mathrm{D}^{\mathrm{r}}$ and $\mathrm{D}^{\mathrm{p}}$ but closest to $\mathrm{D}^{\mathrm{p}}$ it was classified as $\mathrm{D}^{\mathrm{p}}$. $\angle \mathrm{D}^{\mathrm{r}}<\mathrm{D}^{\mathrm{p}}$ is for scans that were between $\mathrm{D}^{\mathrm{p}}$ and $\mathrm{D}^{\mathrm{r}}$ but closest to Dr, likewise for $<\mathrm{Mg}-\mathrm{C}<\mathrm{D}^{\mathrm{p}}$. Samples of P.onkodes that were visibly porous and bio-eroded tended toward $\mathrm{D}^{\mathrm{p}}$ and Mg-calcite and could be broken by hand, whereas the $\mathrm{D}^{\mathrm{r}}$ and magnesite crusts were dense and mostly clean of bio-erosion and required a hammer or considerable force to break. * mineralogy confirmed by SEM, **confirmed by SEM, however not all layers had dolomite rims.

A note on classifying dolomite rich versus dolomite poor. For the experimental data set we identify the asymmetry mol\% of 24 as the figure for delineating between dolomite rich and dolomite poor, however this should not be used as an absolute figure for future studies without first confirming by SEM how the dolomite is present. CCA without magnesite can have dolomite cell lining, dolomite cell in-fill and an XRD curve shape in the dolomite range that matches or is greater than the dolomite rich (asymm. $>27 \mathrm{~mol} \%$ ) samples, yet have an asymmetry mol\% that is only $23-24 \mathrm{~mol} \%$ because of the absence of magnesite (for example, this was the case for P. onkodes from Lizard Is. and PNG). The two samples (H320 and H321) with asymm. mol\% of 23 mol\% (Fig. 1 in the main text) had by XRD a dolomite curve shape that was less than that for the dolomite rich samples with asymm 27 mol\%, however the lower part of the curve extended toward the magnesite position thus giving the reasonably high numerical value. SEM of H320 showed that the dolomite lining though present, was not consistently throughout the sample (Fig. 10 SI) which may explain both the higher asymmetry measurement and the higher amount of dissolution compared to the dolomite rich samples with consistent dolomite cell lining. The asymmetry mol\% method is a tool that allows rapid classification of the mineralogy types present so that those most representative of the groupings can be selected for SEM, this is useful when hundreds of samples are being analysed by XRD. 
Core samples. Rodrigues: The base of this $3.7 \mathrm{~m}$ long core was dated as $3052 \mathrm{yrs}$ old, $+/-258 \mathrm{yrs}$ with an average accretion rate (AAR) of $1.2 \mathrm{~m} / \mathrm{ky}^{35}$. The ages provided in this table are estimates using the published AAR. Heron: this core has not been dated, core drilled 1998 using core equipment in Rees et al. ${ }^{35}$ The mol\% $\mathrm{MgCO}_{3}$ for the $\mathrm{Mg}$-calcite was $15-16 \mathrm{~mol} \% \mathrm{MgCO}_{3} \sim 1-2$ mol\% lower than the fresh samples and this resulted in the asymmetry mol $\%$ for the dolomite rich samples being lower (21-22 mol\% $\mathrm{MgCO}_{3}$ ) than for the fresh samples, however the scan shape in the dolomite range clearly matches fresh samples with confirmed dolomite cell lining.

Spatial variability of mineralogy. Our reef survey included CCA growing on top of dead coral branches and underneath, a maximum distance apart of $2 \mathrm{~cm}$. The CCA on top had dolomite and magnesite, the CCA underneath had a symmetrical XRD scan indicating no dolomite. It seems that mineral variability occurs on a centimetre scale and considering these CCA were both exposed to the same water temperature, chemistry and probably comparable water energy, this suggests that light is the final control on dolomite formation. Mineral variability on a reef scale has not been comprehensively determined however the dolomite rich samples found to date have been from high energy and shallow (less than $5 \mathrm{~m}$ ) environments.

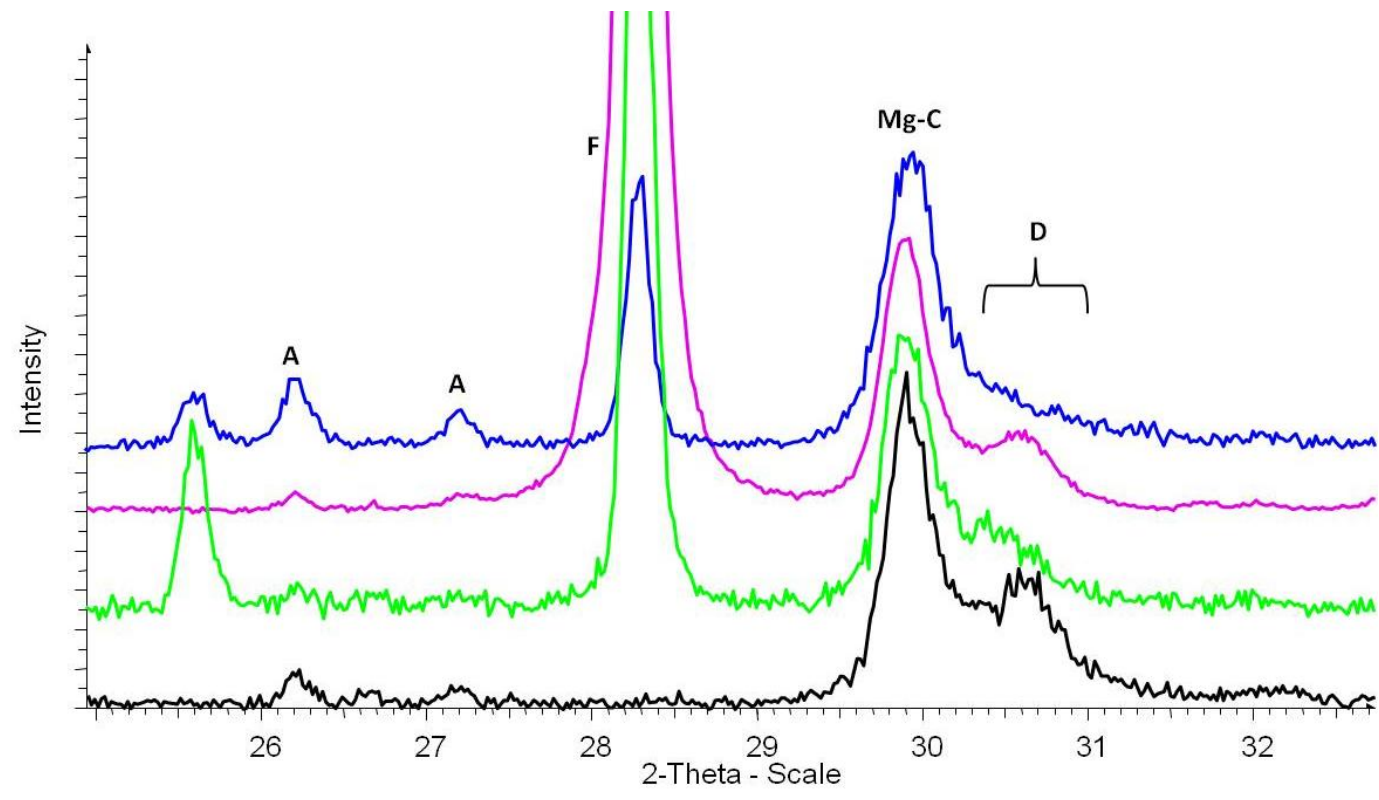

Figure 12: XRD scans from lowest layers of CCA crust for dolomite rich CCA. P.onkodes H305 Heron Island, (Black line), P.onkodes, 07-844, Bise, Okinawajima Island (green). P. pachydermum St. Croix, Caribbean (Pink), P.onkodes, reef front, Heron Is. GBR (Blue). A separate dolomite peak is visible in all but the reef front (blue) sample. Subsamples were taken by very gently scraping the underneath of the CCA crust as this often, but not always, displays a separated peak or increased dolomite asymmetry and thus is easier to confirm the presence of dolomite than using only the bulk sample scan, (following methods in M.C.N. et al., manuscript in preparation) D- dolomite range, MgC- Mg-calcite, F- Fluorite, A- aragonite. 


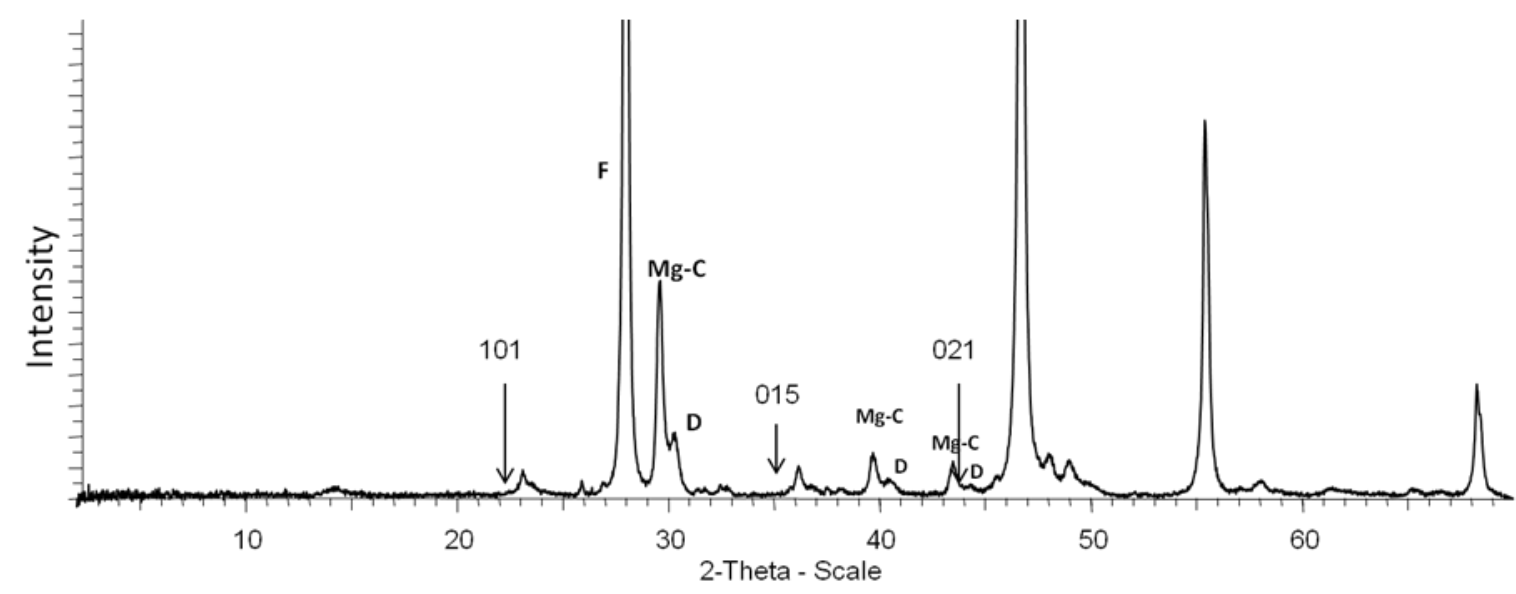

Figure 13: full XRD scan for Caribbean $P$. pachydermum base subsample. No indication of ordering at ordering reflections (101) or (015). Mg-Calcite peak overlies ordering reflection (021).
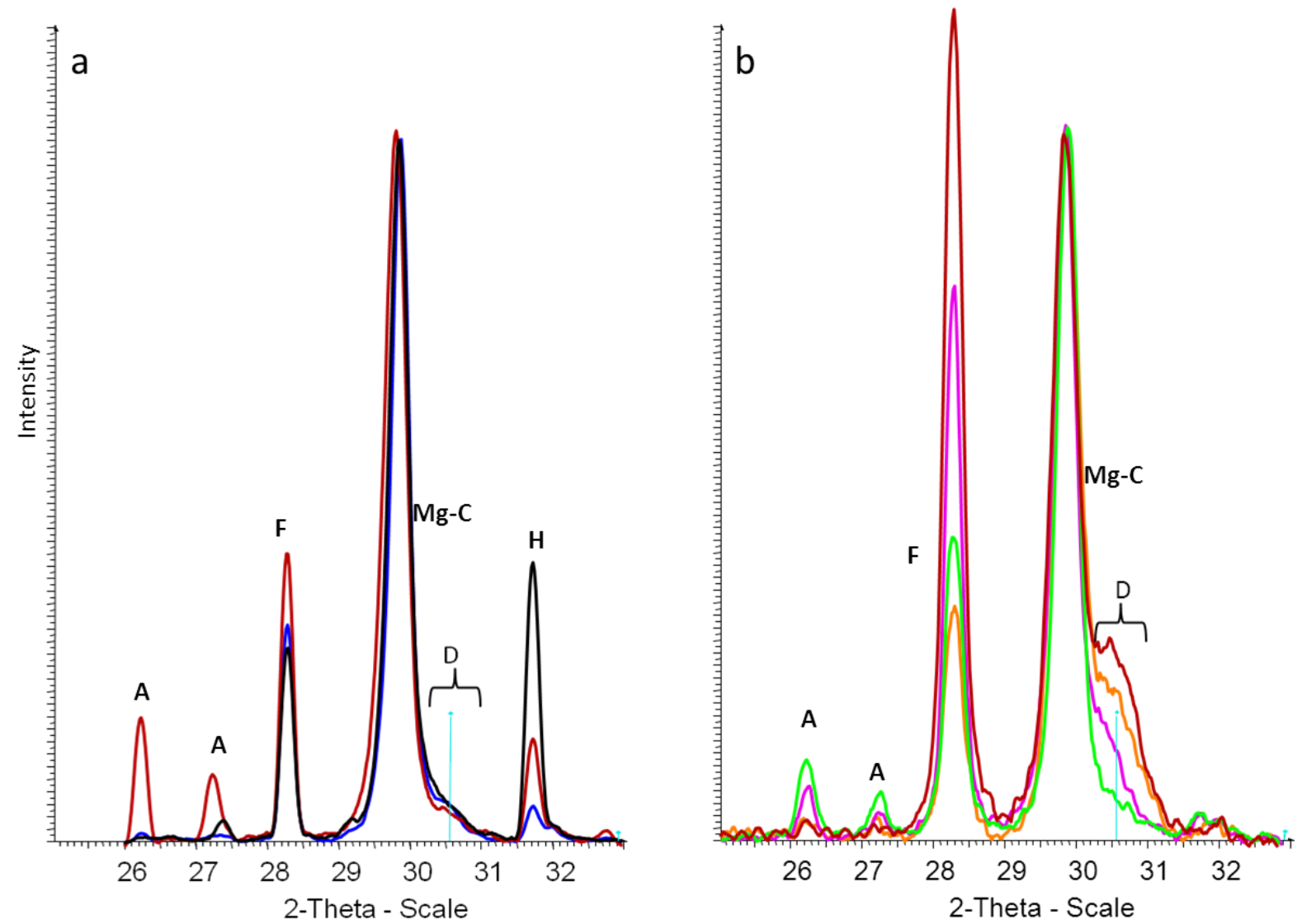

Figure 14: XRD scans for core CCA. a Heron core, red $20 \mathrm{~cm}$, black and blue 5.6 metres, aqua linedisordered dolomite $\sim 50 \mathrm{~mol} \% \mathrm{MgCO}_{3}$. D- dolomite range, $\mathrm{Mg}$-C- Mg-calcite, F- Fluorite, Aaragonite, $\mathrm{H}$ - halite. b Rodrigues core, red $320 \mathrm{~cm}$, orange $35 \mathrm{~cm}$, pink $50 \mathrm{~cm}$, green $80 \mathrm{~cm}$. There is no trend with depth down core and dolomite asymmetry. The dolomite peaks of $320 \mathrm{~cm}$ and $35 \mathrm{~cm}$ are comparable to those from the lowest layer of fresh CCA that had a separate dolomite peak in SI figures 12 and 13. 


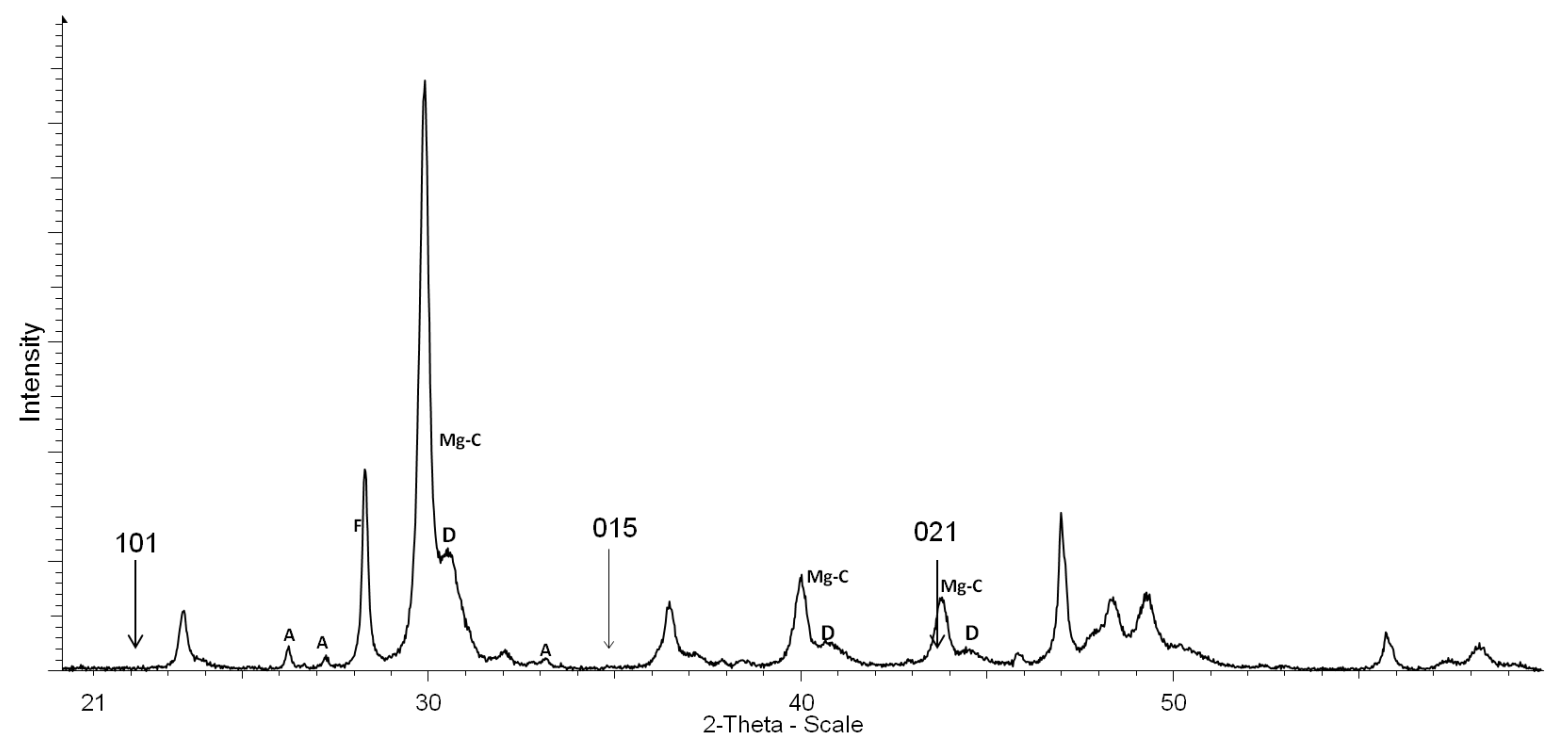

Figure 15: full XRD scan for Rodrigues core CCA at $35 \mathrm{~cm}$. No indication of ordering at ordering reflections (101) or (015). Mg-Calcite peak overlies ordering reflection (021) .

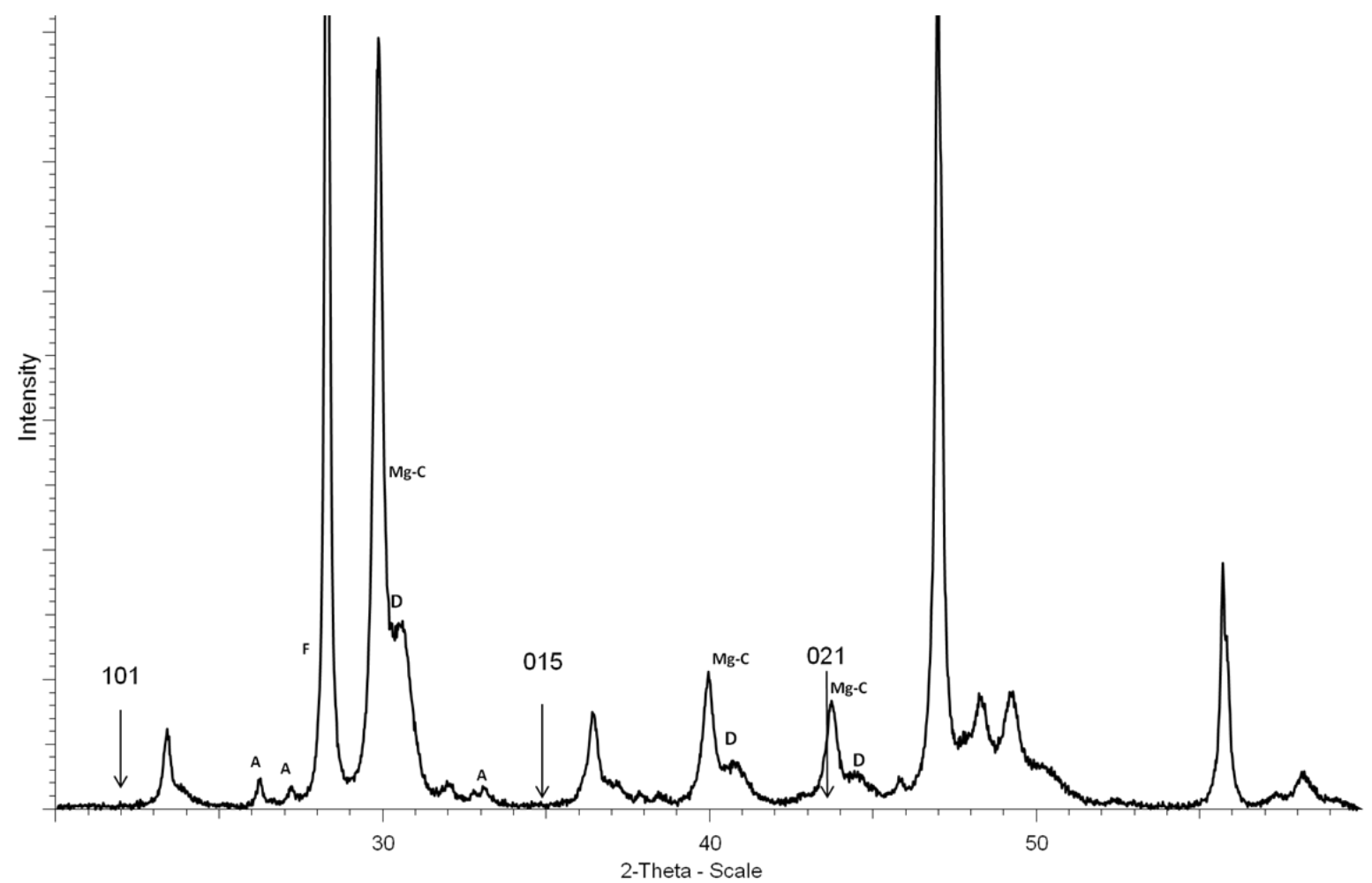

Figure 16: full XRD scan for Rodrigues core CCA at 3.2m. No indication of ordering at ordering reflections (101) or (015). Mg-Calcite peak overlies ordering reflection (021) . 


\section{Re-assessment of mineralogy in published studies for temperate and tropical coralline algae}

\section{Milliman et al. $1971^{36}$}

\begin{tabular}{|c|c|c|c|c|c|c|c|}
\hline \multirow[t]{2}{*}{ Specimen } & \multirow{2}{*}{$\begin{array}{l}\mathrm{Mol} \% \\
\mathrm{MgCO}_{3} \\
(\mathrm{XRD}) *\end{array}$} & \multirow{2}{*}{$\begin{array}{l}\text { Total Mg } \\
\text { by wet } \\
\text { chemistry } \\
* *\end{array}$} & \multirow{2}{*}{$\begin{array}{l}\text { Curve } \\
\text { assessment by } \\
\text { Milliman *** }\end{array}$} & \multicolumn{4}{|c|}{ Our assessment } \\
\hline & & & & Dr, Mag & $\mathrm{Dr}$ & $\mathrm{Dp}$ & Mg-C \\
\hline \multicolumn{8}{|c|}{ Milliman table 1, re-assessment } \\
\hline Jania $\mathrm{sp}$ & 14.3 & 18.6 & Symmetrical & & & & $\mathrm{X}$ \\
\hline Jania $\mathrm{sp}$ & 10.9 & 14.4 & “" & & & & $\mathrm{X}$ \\
\hline Lithothamnium sp & $6.2^{1}$ & 11 & Asymmetrical & & & & $\mathrm{X}$ \\
\hline L. australe & 11.8 & $18^{2}$ & " & & & $\mathrm{X}$ & $?$ \\
\hline L. indicum & 10.8 & 16.5 & “ & & & & $\mathrm{X}$ \\
\hline L. glaciale $^{3}$ & 9.6 & 13 & & & & & $\mathrm{X}$ \\
\hline " & 8.8 & 18.1 & & & $X$ & $?^{4}$ & \\
\hline $\begin{array}{l}\text { Lithophyllum } \\
\text { incrustans }\end{array}$ & 11.3 & 15.1 & Symmetrical & & & & $\mathrm{X}$ \\
\hline L. solutum & 10.6 & 17.7 & “" & & & & $\mathrm{X}$ \\
\hline Porolithon sp. & 16.1 & 28.8 & $\begin{array}{l}\text { Strongly } \\
\text { asymm. }\end{array}$ & $\mathrm{X}$ & & & \\
\hline "6 & 14.4 & 24.2 & " & $?^{5}$ & $\mathrm{X}$ & & \\
\hline $\begin{array}{l}\text { Goniolithon } \\
\text { frutescens }\end{array}$ & 13.6 & 19.2 & Asymmetrical & & & $\mathrm{X}$ & \\
\hline “6 & 16 & 20.65 & “" & & $?$ & $\mathrm{X}$ & \\
\hline “" & 15.1 & 20.7 & “" & & $?$ & $X$ & \\
\hline "6 & 12.8 & 20.6 & “" & & $?$ & $\mathrm{X}$ & \\
\hline G. pallescens & 13.4 & 22.64 & “" & & $\mathrm{X}$ & & \\
\hline G.fosliei & 14.6 & 18.7 & “" & & & $?$ & $\mathrm{X}$ \\
\hline G. strictum & 15.5 & 18.8 & “6 & & & $?$ & $\mathrm{X}$ \\
\hline \multicolumn{8}{|c|}{ Milliman table 2, summary of results, average by genera } \\
\hline $\operatorname{Jania}(\mathrm{n}=10)$ & & & symmetrical & & & & $\mathrm{X}$ \\
\hline Corallina $(\mathrm{n}=6)$ & & & Asymmetrical & & & $\mathrm{X}$ & \\
\hline Amphiroa $(\mathrm{n}=3)$ & & & $\begin{array}{l}\text { Strongly } \\
\text { asymmetrical }\end{array}$ & $?$ & $X$ & & \\
\hline $\begin{array}{l}\text { Lithothamnium } \\
(\mathrm{n}=12)\end{array}$ & & & Asymmetrical & & & $\mathrm{X}$ & \\
\hline $\begin{array}{l}\text { Lithophyllum } \\
(\mathrm{n}=14)\end{array}$ & & & Symmetrical & & & & $\mathrm{X}$ \\
\hline Goniolithon $(\mathrm{n}=7)$ & & & Asymmetrical & & & $\mathrm{X}$ & \\
\hline Porolithon $(\mathrm{n}=3)$ & & & $\begin{array}{l}\text { Strongly } \\
\text { asymmetrical }\end{array}$ & $\mathrm{X}$ & $\mathrm{X}$ & & \\
\hline
\end{tabular}

\section{Table 6a}

* The XRD correlation curve used by Milliman returns approximately 2 mol\% $\mathrm{MgCO}_{3}$ less than using

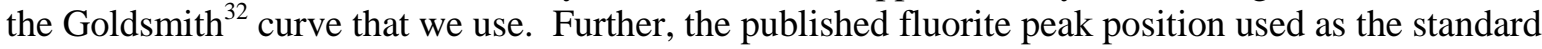
to align the XRD curves has been refined since the 1970's from 3.15 to 3.15564 and this results in a difference of $\sim 1.5 \mathrm{~mol} \%$ in the determination, these two factors together would result in the mol\% $\mathrm{MgCO}_{3}$ being 3-3.5 mol\% higher if the scans were reprocessed using the modern fluorite position and the Goldsmith curve that we used for our analyses. Therefore when considering the difference 
between the XRD mol\% and the bulk (wet chem.) mol\%, a difference of less than 3.5 mol\% could be within measurement error.

** Milliman published this as a total weight $\%$, here it is converted to estimated mol\%.

*** See M.C.N. et al.,(manuscript in preparation) for comparison of these categories to known dolomite CCA XRD results.

${ }^{1}$ Although this has an asymmetrical curve and excess magnesium, the low XRD mol\% indicates that the XRD curve would not have passed over the dolomite range and therefore the excess magnesium was likely present as higher phases of $\mathrm{Mg}$-Calcite up to $25 \mathrm{~mol} \% \mathrm{MgCO}_{3}$.

${ }^{2}$ To compare the total $\mathrm{Mg}$ to $\mathrm{Mol} \% \mathrm{MgCO}_{3}$ by XRD we use an estimate of what the excess magnesium will be. $\mathrm{D}^{\mathrm{p}}$ - presuming a maximum of $5 \%$ of the sample is dolomite (i.e. conceptacle spaces) and $\mathrm{Mg}$-calcite $\mathrm{Mol} \% \mathrm{MgCO}_{3}$ is $16.5 \mathrm{~mol} \%$, then bulk will be $17.9 \%$, an excess of $1.4 \mathrm{~mol} \%$ $\mathrm{MgCO} 3 . \mathrm{D}^{\mathrm{r}}$-, estimating dolomite content to range from $18-25 \%$ of the total, then bulk $\mathrm{Mg}=\sim 21.6$ $-23.6 \mathrm{~mol} \% \mathrm{MgCO}_{3}$, for bulk measurements significantly higher than these it is considered likely that magnesite is present. Note that aragonite is present in many CCA samples thus diluting the bulk $\mathrm{Mg}$ measurements and it is possible that samples classified as $\mathrm{Mg}-\mathrm{C}$ based on this comparison may be $\mathrm{D}^{\mathrm{p}}$ or $\mathrm{D}^{\mathrm{r}}$.

${ }^{3}$ Milliman noted that the Mg-calcite peaks for the tropical L. glaciale were more asymmetrical than the temperate. The collection locations are not recorded in Milliman's table.

${ }^{4}$ Where the assessment is uncertain, X marks the most likely and ? the other possible assessment.

${ }^{5}$ This lower bulk Mg may be a result of aragonite in the skeleton diluting the final $\mathrm{mol} \% \mathrm{MgCO}_{3}$ or it is possible that most cell in-fill is by dolomite rather than magnesite as seen in discrete bands in Fig. 3.

\section{Chave $1954^{37}$}

\begin{tabular}{|c|c|c|c|c|c|c|c|c|}
\hline Location & Temp. & Specimen & $\begin{array}{l}\mathrm{Mol} \% \\
\mathrm{MgCO}_{3} \\
\text { (XRD) } \\
\end{array}$ & $\begin{array}{l}\text { Total Mg by } \\
\text { wet } \\
\text { chemistry }\end{array}$ & \multicolumn{4}{|c|}{ Our assessment } \\
\hline & & & & & Dr, Mag & Dr & $\mathrm{Dp}$ & $\mathrm{Mg}-\mathrm{C}$ \\
\hline $\begin{array}{l}\text { Adak Is. } \\
\text { Alaska }\end{array}$ & 5.2 & Lithothamnion sp. & 9 & & & & & $\mathrm{X}$ \\
\hline 6 & “ & “ & 7.7 & & & & & $\mathrm{X}$ \\
\hline $\begin{array}{l}\text { Mount Desert, } \\
\text { Maine }\end{array}$ & 6 & “ & 12 & & & & & $\mathrm{X}$ \\
\hline "6 & “6 & “" & 12 & & & & & $\mathrm{X}$ \\
\hline Honshu, Japan & 15.5 & “ & 15.2 & & & & & $\mathrm{X}$ \\
\hline La Jolla, Calif. & 17 & Bossea sp. & 11.9 & & & & & $\mathrm{X}$ \\
\hline “" & “" & Lithothamnium sp. & 14.1 & & & & & $\mathrm{X}$ \\
\hline $\begin{array}{l}\text { Okinoshima, } \\
\text { Japan }\end{array}$ & 18 & " & 15.5 & & & & & $\mathrm{X}$ \\
\hline Bermuda & 23 & Amphiroa sp. & & 22.36 & & $\mathrm{X}$ & & \\
\hline "6 & “" & Lithothamnium sp. & 16.4 & & & & & $\mathrm{X}$ \\
\hline “" & “ & " & & 14.85 & & & & $\mathrm{X}$ \\
\hline Florida keys & 26 & Goniolithon sp. & & 25.95 & $\mathrm{X}$ & & & \\
\hline "6 & $"$ & “ & & 28.75 & $X$ & & & \\
\hline Palau & 28 & Lithophyllum sp. & & 20.93 & & $\mathrm{X}$ & $?$ & \\
\hline Guam & " & “" & & 21.07 & & $\mathrm{X}$ & $?$ & \\
\hline
\end{tabular}

Table 6b

\section{Other studies}

\begin{tabular}{|l|l|l|l|l|l}
\hline Location & Temp. & Specimen & Mol\% & Total Mg by & Our assessment \\
\hline
\end{tabular}




\begin{tabular}{|c|c|c|c|c|c|c|c|c|}
\hline & & & $\begin{array}{l}\mathrm{MgCO}_{3} \\
\text { (XRD) }\end{array}$ & wet chemistry & & & & \\
\hline & & & & & Dr,Mag & $\mathrm{Dr}$ & $\mathrm{Dp}$ & $\mathrm{Mg}-\mathrm{C}$ \\
\hline & & Goniolithon $^{38}$ & 18.1 & 22.3 & & $\mathrm{X}$ & & \\
\hline & & Neogoniolithon $^{38}$ & 18 & 23 & & $\mathrm{X}$ & & \\
\hline & & Amphiroa rigida ${ }^{39}$ & & See Fig. 12 SI & & $\mathrm{X}$ & $?$ & \\
\hline Corsica & & Lithothamnium $\mathrm{sp}^{40}$ & & $15.5^{4}$ & & & $\mathrm{X}$ & $?$ \\
\hline Bermuda & & Amphiroa $^{41}$ & & $19.5^{4}$ & & $\mathrm{X}$ & & \\
\hline Bermuda & & $\begin{array}{l}\text { Amphiroa } \\
\text { fragilissima } 42\end{array}$ & 17.5 & & & & & $\mathrm{X}$ \\
\hline Rodriguez & & Goniolithon $^{43}$ & 21 & $24-29^{5}$ & $\mathrm{X}$ & $\mathrm{X}$ & & \\
\hline $\begin{array}{l}\text { Marshall Is, } \\
\text { Likiep atoll }\end{array}$ & $\begin{array}{l}27.4 \\
- \\
29.3\end{array}$ & Goniolithon $^{44,45}$ & & $\begin{array}{l}\text { Author } \\
\text { description }\end{array}$ & & $X$ & & \\
\hline “" & " & P. gardineri “ & & $\begin{array}{l}\text { Noted Mg- } \\
\text { rich rims } \\
\text { dolomite } \\
\text { composition }\end{array}$ & $\mathrm{X}$ & & & \\
\hline $\begin{array}{l}\text { Tuamotu Is, } \\
\text { Raroia atoll }\end{array}$ & $\begin{array}{l}26.1- \\
27.5 \\
\end{array}$ & $\begin{array}{l}\text { P. aequinoctiale } \\
\text { FOSLIE " }\end{array}$ & & $\begin{array}{l}(48-49) \\
\text { microprobe }\end{array}$ & & $X$ & $?$ & \\
\hline $\begin{array}{l}\text { Marshall Is, } \\
\text { Ujae Atoll }\end{array}$ & $\begin{array}{l}27.5 \\
- \\
29.9\end{array}$ & P.onkodes " & & $\begin{array}{l}53 \\
\text { Microprobe }\end{array}$ & & $X$ & ? & \\
\hline
\end{tabular}

\section{Table 6c}

${ }^{4}$ Bischoff noted that both samples had broadened XRD curves however the Lithothamnium was strongly asymmetric and electron microprobe of both samples detected domains with up to $10 \mathrm{~mol} \%$ $\mathrm{MgCO}_{3}$ higher than the average.

${ }^{5}$ Schmalz detected brucite in one and only one sample of many analysed that had 24-29 mol\% $\mathrm{MgCO}_{3}$. The published XRD pattern shows asymmetry with a visible hump on the dolomite side of the $\mathrm{Mg}$-calcite peak and possible magnesite shoulder.

${ }^{6}$ Spot measurements by electron microprobe. Results of Moberly ${ }^{44}$ discussed in Nash et al. ${ }^{34}$. Moberly discussed at length the presence of magnesium rich conceptacles, magnesium enriched linings in cells (approaching dolomite) in Goniolithon and Porolithon from the tropical pacific and measured magnesite in a conceptacle of $P$. Gardineri

\section{Clarke and Wheeler $1922^{46}$}

\begin{tabular}{|l|l|l|l|l|l|l|l|l|}
\hline Location & Temp & $\begin{array}{l}\text { Specimen } \\
\text { **all collected } \\
\text { from reefs, rocks } \\
\text { or near low tide } \\
\text { level** }\end{array}$ & $\begin{array}{l}\text { No } \\
\text { XRD }\end{array}$ & $\begin{array}{l}\text { Total Mg } \\
\text { by wet } \\
\text { chemistry }\end{array}$ & \multicolumn{2}{l|}{ Our assessment } \\
\hline
\end{tabular}




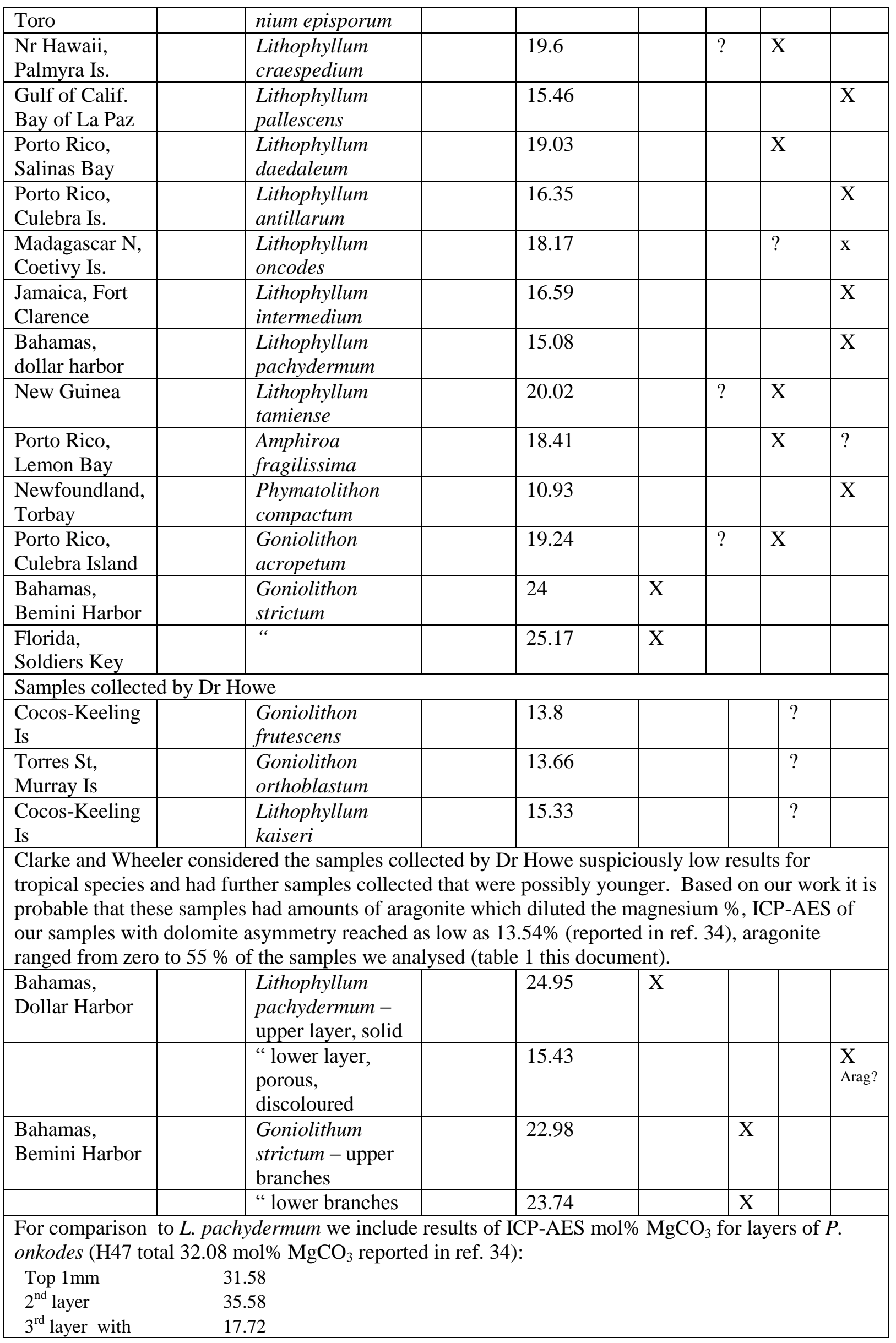




\begin{tabular}{|l|l|l|l|l|l|l|l|l|}
\hline Samoa & Calcareous algae & & 36.36 & $\mathrm{X}$ & & & \\
\hline $\begin{array}{l}\text { Sth Florida, } \\
\text { Tortugas }\end{array}$ & 6 & & 25.32 & $\mathrm{X}$ & & & \\
\hline
\end{tabular}

Tortugas Results from A. Damour

\begin{tabular}{|l|l|l|l|l|l|l|l|}
\hline $\begin{array}{l}\text { Mediterranean } \\
\text { Sea }\end{array}$ & Lithophyllum & & 12.76 & & & & $\begin{array}{l}\text { X? } \\
\text { arag }\end{array}$ \\
\hline $\begin{array}{l}\text { Coast of } \\
\text { Algeria }\end{array}$ & Melobesia sp & & 14.44 & & & & $\begin{array}{l}\text { X? } \\
\text { arag }\end{array}$ \\
\hline Antilles & Amphiroa tribulus & & 19.29 & & $?$ & X & \\
\hline
\end{tabular}

Other tables included in Clarke and Wheeler are excluded as Mg contents recognized by authors as being significantly lower than theirs and perhaps not reliable or representative.

Table 6d

Mineralogy summary for main algal ridge coralline algae

\begin{tabular}{|c|c|c|c|}
\hline Location & CCA & $D^{\mathrm{R}}$, Mag & $\mathbf{D}^{\mathrm{r}}$ \\
\hline Florida keys $^{\mathrm{a}}$ & Goniolithon sp. & $\mathrm{X}$ & \\
\hline " & G. strictum & $\mathrm{X}$ & \\
\hline Rodriguez $^{\mathrm{a}, \mathrm{b}}$ & Goniolithon sp. & $\mathrm{X}$ & \\
\hline Marshall Is. ${ }^{a}$ & “ & & $\mathrm{X}$ \\
\hline " & Porolithon gardineri & $\mathrm{X}$ & \\
\hline “ & P.onkodes & & $\mathrm{X}$ \\
\hline Tuamatu $^{a}$ & P. aequinoctiale & & $\mathrm{X}$ \\
\hline Bahamas $^{a}$ & G. strictum & $\mathrm{X}$ & \\
\hline Samoa ${ }^{a}$ & Unidentified CCA & $\mathrm{X}$ & \\
\hline GBR- Heron Is. ${ }^{b}$ & P.onkodes & $\mathrm{X}$ & \\
\hline GBR-Lizard Is. ${ }^{b}$ & P.onkodes & & $\mathrm{X}$ \\
\hline Ryukyu islands ${ }^{\mathrm{b}}$ & \begin{tabular}{|l} 
P.onkodes \\
\end{tabular} & $\mathrm{X}$ & \\
\hline Caribbean $^{\mathrm{b}}$ & P.pachydermum & $\mathrm{X}$ & \\
\hline $\mathrm{PNG}^{\mathrm{b}}$ & \begin{tabular}{|l|} 
P.onkodes \\
\end{tabular} & & $\mathrm{X}$ \\
\hline
\end{tabular}

Table 6e: Highest magnesium mineral composition assessed / measured for algal ridge coralline algae.

${ }^{\text {a }}$ summary of previous studies tables 6a-d.

${ }^{\mathrm{b}}$ this study 


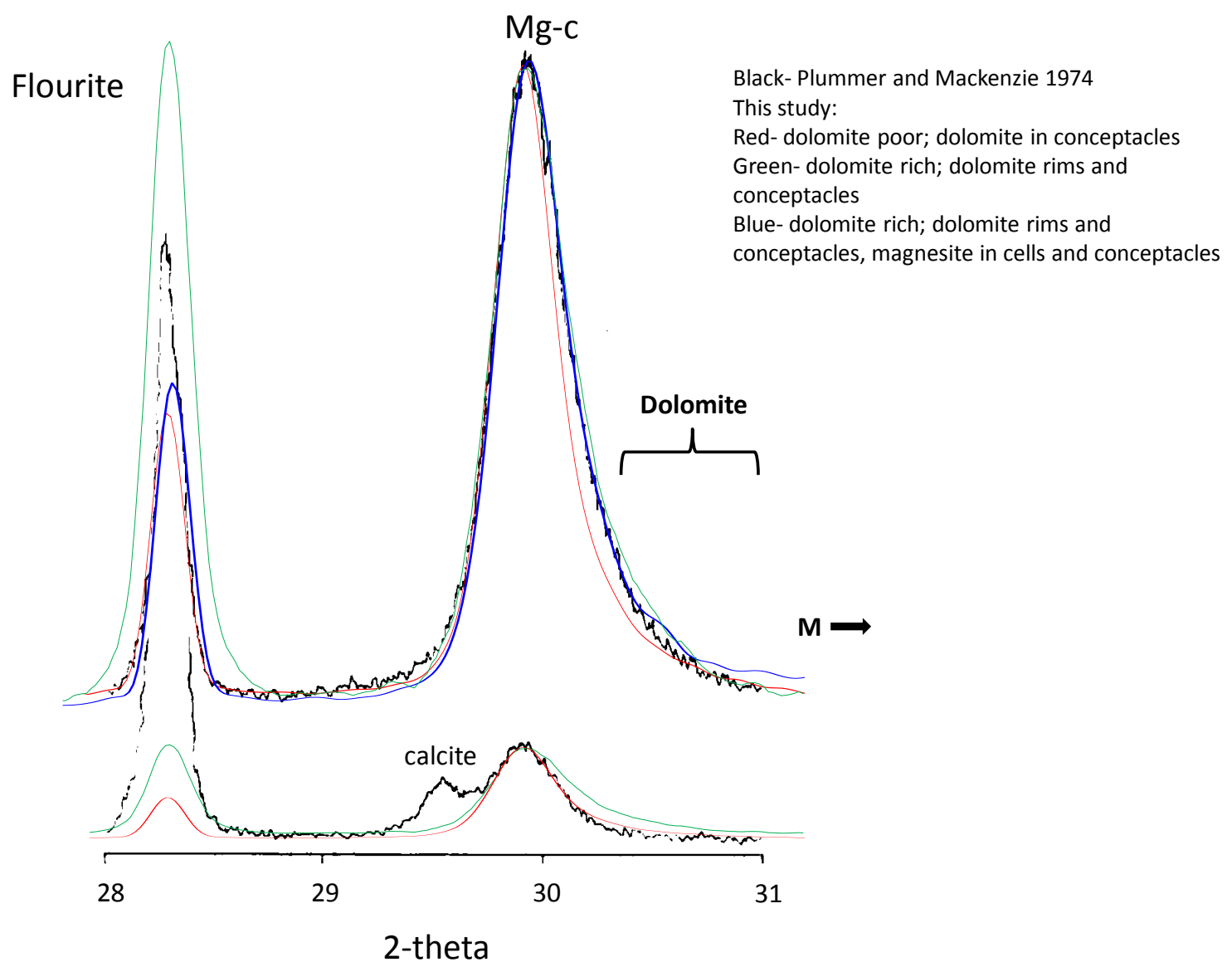

Figure 17: Comparison of XRD analysis for samples with mineralogy confirmed by SEM to XRD results for coralline alga Amphiroa rigida used in Plummer et al. ${ }^{40}$. The top panel is XRD before the Plummer dissolution experiment and the bottom XRD is their sample after their 70 day experiment. In the top figure our $\mathrm{D}^{\mathrm{p}}$ (red) sample demonstrates less asymmetry than the A.rigida indicating the $A$. rigida must have had at least conceptacle dolomite. Our $\mathrm{D}^{\mathrm{r}}$ with magnesite (blue) line traces the $A$. rigida line down to half way through the dolomite range and then levels out to extend to the magnesite position (M), this suggests that the A.rigida may have also had dolomite rims but not magnesite. The green line is an XRD for another P. onkodes (not in this study) examined in our lab that had dolomite rims and conceptacles and no magnesite (all confirmed by SEM-EDS). The close fit of this line to the A.rigida strongly suggests that A.rigida may have had dolomite rims and conceptacle dolomite. After dissolution the A.rigida now demonstrates slightly less asymmetry than our $\mathrm{D}^{\mathrm{p}}$ sample suggesting that most the dolomite has been dissolved. This is in contrast to the lower layers of our samples exposed to seawater and undergoing natural dissolution processes where in-situ dolomite remains and there is often aragonite but no measurable calcite indicating that diagenetic alteration progresses differently in laboratory conditions. 


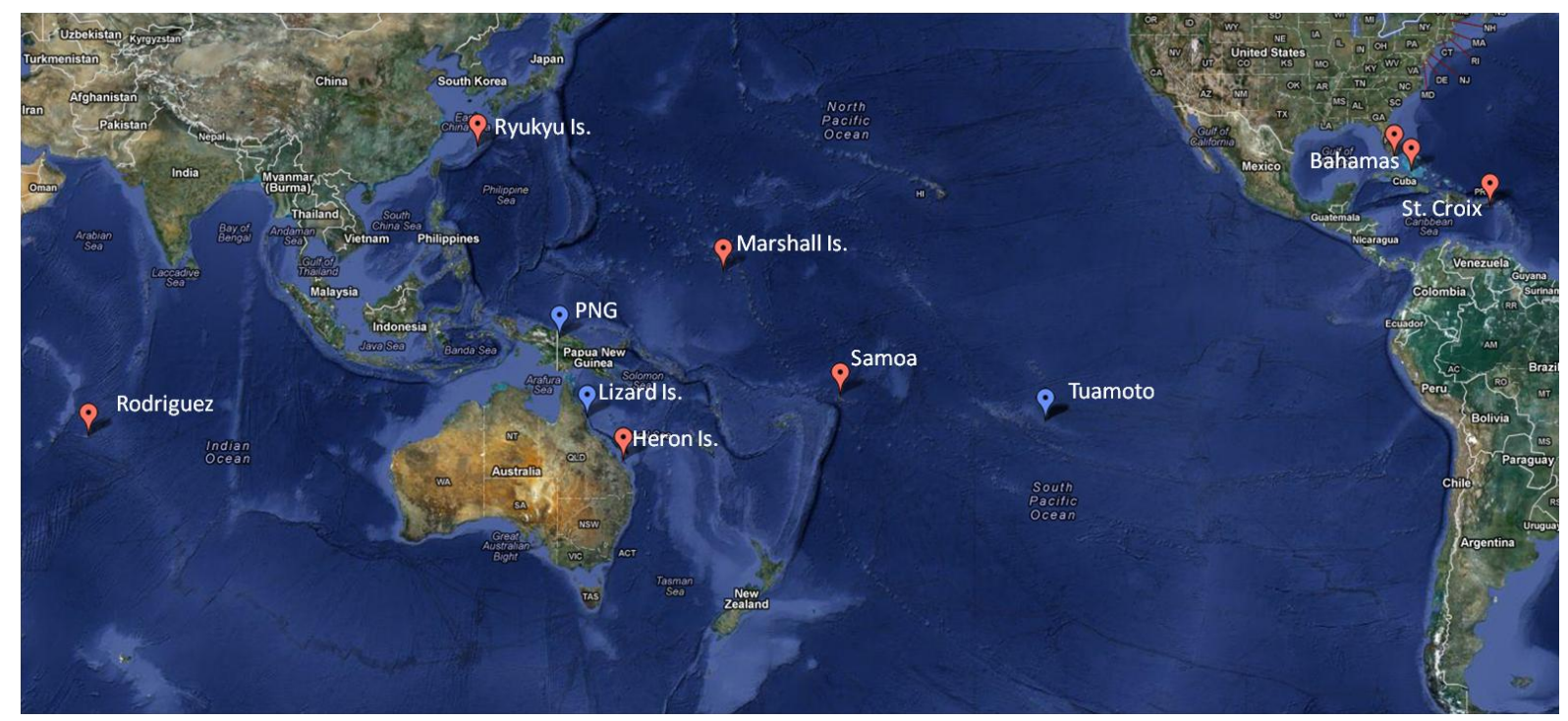

Map 1: Global distribution of Dolomite rich algal ridge coralline algae. Red icons are $\mathrm{D}^{\mathrm{r}}$ and magnesite, blue is only $\mathrm{D}^{\mathrm{r}}$ (map source: Google earth)

\section{References}

30. Kline, D.I., Teneva, L., Schneider, K., Miard, T. \& Chai, A. et al. A short-term in situ CO2 enrichment experiment on Heron Island (GBR). Scientific Reports 2, 413 (2012).

31. Santos, I.R., Glud, R.N., Maher, D. \& Eyre, B.D. Diel coral reef acidification driven by pore water advection in permeable carbonate sands, Heron Island, Great Barrier Reef. Geophysical Research Letters 38, L03604 (2011).

32. Goldsmith, J.R., Graf, D.L. \& Joensuu, O.I. The occurrence of magnesian calcites in nature. Geochimica et Cosmochimica Acta 7, (5) 212-230 (1955).

33. Sepulcre, S., Durand, N. \& Bard, E. Mineralogical determination of reef and periplatform carbonates: Calibration and implications for paleoceanography and radiochronology. Global and Planetary Change 66, (1-2) 1-9 (2009).

34. Nash, M.C., Troitzsch, U., Opdyke, B.N., Trafford, J.M., Russell B.D. et al. First discovery of dolomite and magnesite in living coralline algae and its geobiological implications.

Biogeosciences 8, 3331-3340 (2011).

35. Rees, S.A., Opdyke, B.N., Wilson, P.A., \& Fifield, L.K. Coral reef sedimentation on Rodrigues and the Western Indian Ocean and its impact on the carbon cycle, Philosophical Transactions of the Royal Society A: Mathematical, Physical and Engineering Sciences 363, 101-120 (2005).

36. Milliman, J.D., Gastner, M. \& Muller, J. Utilization of Magnesium in Coralline Algae. Geological Society of America Bulletin 82, (3) 573-580 (1971).

37. Chave, K.E., Aspects of the Biogeochemistry of Magnesium 1. Calcareous Marine Organisms. Journal of Geology 62, (3) 266-283 (1954).

38. Walter, L.W. \& Morse, J.W. The dissolution kinetics of shallow marine carbonates in seawater: A laboratory study. Geochemica et Cosmochimica Acta 49, 1503-1513 (1985).

39. Plummer, L.N. \& Mackenzie, F.T. Predicting mineral solubility from rate data: application to the dissolution of magnesian calcites. American Journal of Science 274, 61-83 (1974).

40. Bischoff, W.D., Bishop, F.C., \& Mackenzie, F.T. Biogenically produced magnesian calcite: in homogeneities in chemical and physical properties; comparison with synthetic phases. American Mineralogist 68, (11-12) 1183-1188 (1983). 
41. Mackenzie, F.T., Bischoff, W.D., Bishop, F.C., Loijens, M., Schoonmaker, J. et al. Magnesian calcites; low-temperature occurrence, solubility and solid-solution behavior. Reviews in Mineralogy and Geochemistry 11, (1) 97-144 (1983).

42. Henrich, R. \& Wefer, G. Dissolution of biogenic carbonates: Effects of skeletal structure. Marine Geology 71, 341-362 (1986).

43. Schmalz, R.F. Brucite in Carbonate Secreted by the Red Algae Goniolithon sp. Science 149, 993-996 (1965).

44. Moberly, R. Microprobe study of diagenesis in calcareous algae. Sedimentology 14, 113-123 (1970).

45. Moberly, R. Composition of magnesian calcites of algae and pelecypods by electron microprobe analysis. Sedimentology 11, 61-82 (1968).

46. Clarke, F.W. \& Wheeler, W.C. The inorganic constituents of marine invertebrates. USGS, Prof. Pap. 124, 1-62 (1922). 